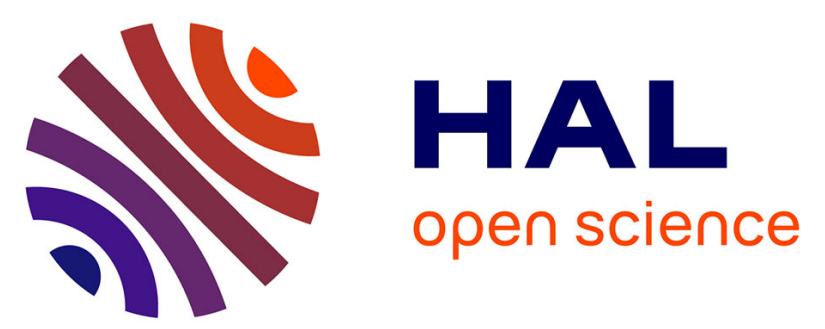

\title{
Spatio-temporal evolution of temperature and fluid flow through a new "thermo-lithological" boundary; the case of a pit crater of Karthala volcano (Comoros archipelago) refilled on January 13th 2007 by a lava flow \\ Noé Bernabeu, Anthony Finizola, Claude Smutek, Pierre Saramito, Eric
} Delcher

\section{To cite this version:}

Noé Bernabeu, Anthony Finizola, Claude Smutek, Pierre Saramito, Eric Delcher. Spatio-temporal evolution of temperature and fluid flow through a new "thermo-lithological" boundary; the case of a pit crater of Karthala volcano (Comoros archipelago) refilled on January 13th 2007 by a lava flow. Journal of Volcanology and Geothermal Research, 2018, 367, pp.7-19. 10.1016/j.jvolgeores.2018.10.013 . hal01809884

\section{HAL Id: hal-01809884 \\ https://hal.science/hal-01809884}

Submitted on 30 Oct 2018

HAL is a multi-disciplinary open access archive for the deposit and dissemination of scientific research documents, whether they are published or not. The documents may come from teaching and research institutions in France or abroad, or from public or private research centers.
L'archive ouverte pluridisciplinaire HAL, est destinée au dépôt et à la diffusion de documents scientifiques de niveau recherche, publiés ou non, émanant des établissements d'enseignement et de recherche français ou étrangers, des laboratoires publics ou privés. 


\title{
Spatio-temporal evolution of temperature and fluid flow through a new "thermo-lithological" boundary; the case of a pit crater of Karthala volcano (Comoros archipelago) refilled on January $13^{\text {th }} 2007$ by a lava flow.
}

Noé Bernabeu $^{\mathrm{a}, \mathrm{b}^{*}}$, Anthony Finizola ${ }^{\mathrm{b}}$, Claude Smutek ${ }^{\mathrm{b}}$, Pierre Saramito ${ }^{\mathrm{a}}$, Eric Delcher ${ }^{\mathrm{b}}$

${ }^{\text {a }}$ Laboratoire Jean Kuntzmann, UMR 5524, Université J. Fourier - Grenoble I and CNRS, BP 53, F-38041 Grenoble cedex, France

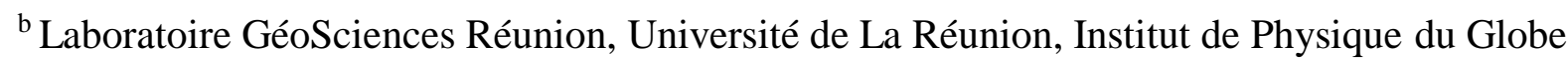
de Paris, Sorbonne Paris-Cité, CNRS, UMR 7154, Saint-Denis, La Réunion, France

*Corresponding author: noe.bernabeu@gmail.com

\begin{abstract}
On January $13^{\text {th }} 2007$ an effusive eruption on the top of Karthala volcano, in the Comoros islands, emitted a lava flow which has been perfectly constrained inside the cylindrical shape of the Choungou Chagnoumeni pit crater; $225 \mathrm{~m}$ in diameter and with a thickness of about $7 \mathrm{~m}$.

This eruptive event, with a known geometry before the eruptive event, give a unique opportunity to study a "thermo-lithological" structural boundary recently born, and follow its thermal and fluid flow evolution in time.

The motivation of this survey is to better understand some scientific questions such as: How fluid flows evolve in time along a new thermo-lithological boundary? How lava temperature cooling induce changes in hydrothermal circulation?Different data set have been acquired on the field in order to discuss these problematics. On March 2008, a temperature monitoring was installed with a data logger (CR 1000 Campbell Scientific) and 11 sensors placed at 30 $\mathrm{cm}$ depth, 1 meter apart, inside the crater, along a straight profile, perpendicular to the western rim of the Choungou Chagnoumeni crater. Data were recorded during 275 days out of 677 days, through 4 different periods between $3^{\text {rd }}$ March 2008 and $8^{\text {th }}$ January 2010.
\end{abstract}


On June 2009, high resolution electrical resistivity tomography (ERT) coupled with soil $\mathrm{CO}_{2}$ diffuse degassing was performed above the monitoring line of temperature sensors along a profile of $128 \mathrm{~m}$ long, with ERT electrodes and $\mathrm{CO}_{2}$ measurements located each $2 \mathrm{~m}$.

Numerical modeling of the temperatures was also tested on this case study, thanks to the Rheolef code. The aim of using a numerical code, integrating a maximum of parameters, have been to better interpret the other data acquired on the field.

The lateral permeability transition induced by the crater refilled with lava flow material was attested by the soil diffuse degassing profile.

Coupling ERT and temperature modeling allow evidencing the heat transfer with conductive processes.

The most striking result has been the inversion of the lateral temperature gradient which evolves during the first three years of cooling, from the highest temperature in direction to the center of the crater to the highest temperature in direction to the boundary of the crater.

Such a result highlights the importance of structural boundary in dragging hydrothermal fluids and has been interpreted by a change in the main parameter governing the heat transfer close to the boundary of the crater, which evolved from (1) a lava heat source toward (2) a higher permeability area constituted by the boundary of the crater. This study clearly displays the importance of the lateral permeability gradient in changing the hydrothermal circulation in time.

Keywords: lava flow, cooling, temperature numerical modeling, temperature monitoring, electrical resistivity tomography, permeability, fluid flow, diffuse degassing, Karthala volcano, Comoros islands. 


\section{Introduction}

\subsection{General context}

On active volcanoes, temperature appears as one of the most intuitive parameter to look for precursors of major or paroxysmal eruptive activity. This parameter can be measured directly by temperature sensors inserted into the soil (Friedel et al., 2004; Ricci et al., 2015; Gaudin et al., 2017) or by remote sensors (Wright et al., 2004; Coppola et al., 2015a; Laiolo et al., 2017). Thermal anomalies recorded on active volcanoes can be subdivided into two groups depending on how the heat transfer is directed toward the surface:

First, the anomalies related to hydrothermal fluid flow condense in the atmosphere or close to the surface (Aubert, 1999; Aubert et al., 2008). These are of low amplitude, generally reaching just the threshold of the water ebullition point. These hot fluids are generally underlining structural discontinuities with higher permeability such as crater or caldera rims or tectonic faults, along which fluids flow preferentially (Finizola et al., 2003, 2006; BardeCabusson et al., 2009a; Antoine et al., 2009; Revil et al., 2004, 2008, 2011; Peltier et al., 2012). Sometimes, temperatures are much higher (several hundred of degrees), because gases escaped from magma at depth and reach the surface without temperatures be buffered by hydrothermal systems (Chiodini et al., 1995).

Second, anomalies of higher amplitude, generally above $100^{\circ} \mathrm{C}$, are directly related to lava flows or lava lakes (Wright et al., 2001, Harris et al., 1999, 2002, 2005; Coppola and Cigolini, 2013; Coppola et al., 2015b).

While hydrothermal origin anomalies expand generally over few tens up to few hundred meters large (Finizola et al., 2002; Bennati et al., 2011), magmatic origin anomalies can extend over larger distance (Harris et al., 1997; Barde-Cabusson et al., 2009b; Coppola et al., 2009). Sometimes, interaction between these two systems occurs; because structural boundaries are also higher permeability areas where magma can migrate toward the surface.

In our study case, on Karthala volcano, in Comoros islands, the eruption of $13^{\text {th }}$ January 2007 and its lava flow that refilled a near perfect cylindrical volume constituting the Choungou Chagnoumeni crater, give a unique opportunity to study a hot structural boundary recently born, and follow its thermal and fluid flow evolution in time.

The motivation of this survey is to better understand scientific questions such as:

How fluid flow evolve in time along a new "thermo-lithological” boundary? 
How lava temperature cooling induce changes in hydrothermal circulation?

Such problematic are interesting not only in volcanology in term of time evolution in fluid circulation and self-sealing along a structural boundary (Finizola et al., 2009; Revil et al., submitted), but also in mining geology for related mineralization induced by magmatic/hydrothermal fluid flow (Hedenquist and Henley, 1985; Hedenquist and Lowenstern, 1994).

In this study, soil heterogeneity and spatial distribution of relative lateral changes in soil permeability is assessed coupling soil gas technique and electrical resistivity tomography (Finizola et al., 2006; Revil et al., 2011).

Numerical temperature modeling is used to locate the spatio-temporal evolution of temperature imposed by the lava cooling. Considering that the distribution in space of the true permeability values is not known, we decided to not introduce in the model parameters strongly affected by permeability variations; as a consequence, convection at depth have not been considered in the model. Details of the different parameters taken into account in the numerical temperature modeling are specified in the following chapters.

Temperature monitoring at $30 \mathrm{~cm}$ depth have been installed along a straight line of 10 meters long, with 1 meter apart, perpendicularly and inside the crater rim, to study (1) the general temperature cooling in time, (2) the lateral influence of the structural boundary, and (3) the location of the most active convective area and its evolution in time.

\subsection{Geological framework}

Karthala (2,361 m a.s.1.) is an active basaltic shield volcano located on Grande Comore Island, the youngest and the most westerly of the four volcanic islands of the Comoros Archipelago (Bachèlery and Hémond, 2016). Located between the northern Madagascar and Mozambique (Fig. 1a), this alkali volcanism constitute a possible extension of the East African rift (Michon, 2016). Petrology of Karthala volcano is mainly constituted of basalt and few hawaiite (Bachèlery and Hémond, 2016). 

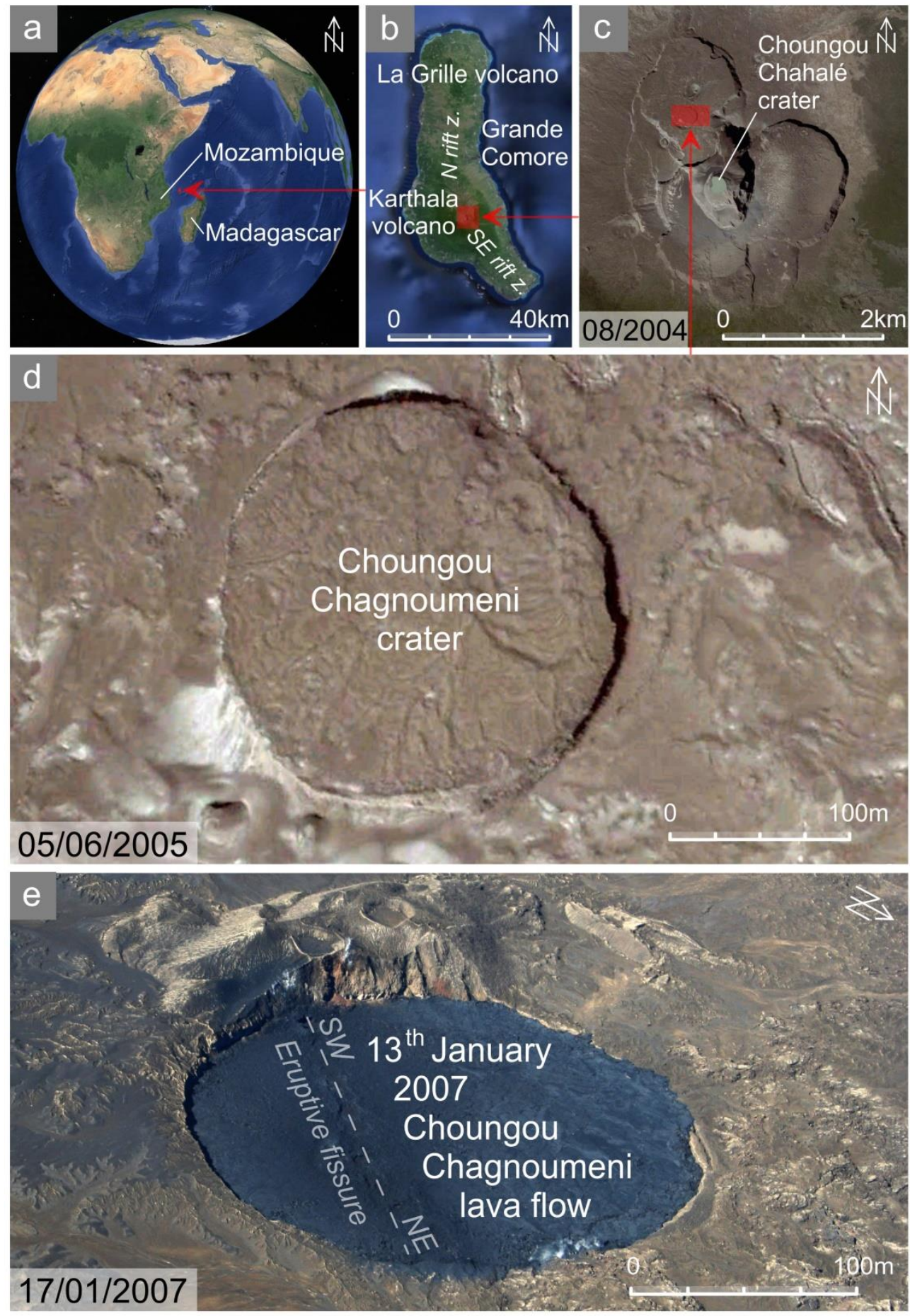

Figure 1: (a) Location on Google Earth of Comoros archipelago, between Mozambique and Madagascar; (b) Google Earth picture of Grande Comore island; (c) Google Earth picture of the summit calderas of Karthala volcano; (d) Google Earth picture of the Choungou Chagnoumeni crater before the January $13^{\text {th }} 2007$ eruption (e) Aerial picture of the Choungou Chagnoumeni crater after the January $13^{\text {th }} 2007$ eruption (courtesy of P. Bachèlery). 
The Island of Grande Comore is subdivided into two main quaternary volcanic edifices; (1) La Grille volcano, the oldest one located on the north, and (2) the Karthala volcano, forming the southern two-third of the island (Fig. 1b). The shape of the island is underlining the two main rift zones (North and South East) crossing the volcanic edifice. The summit part of Karthala is characterized by a polylobate caldera complex approximately elliptical $(3.5 \times 2.8$ km) (Strong and Jacquot, 1970; see Fig. 1c). The eruptive style is mostly effusive along the rift zones, with eruptions along eruptive fissures, but also far from the rift zones at low elevation, or inside the summit caldera (Krafft, 1982; Bachèlery and Coudray, 1993). However, the non-permanent summit water lake located inside the main crater (ChoungouChahalé crater; see Fig. 1c) is also responsible of phreatic or phreatomagmatic eruptions, whose ash deposits affect generally all the Grande Comore Island (Bachèlery et al., 1995, 2016b; Morin et al., 2016).

Since the beginning of the $19^{\text {th }}$ century, a total 39 eruptions have been recorded but of which 14 remains uncertain. Karthala volcanic activity can be assimilated to a typical shield volcano activity, constituted mainly of eruptive fissures, lava flows of pahoehoe and aa type and scoria cones, sometimes disrupted by phreatic or phreato-magmatic events.

This recent eruptive activity of Karthala can be subdivided into three main periods where the eruptive activity was located geographically in three different areas:

1) During the first one, between 1848 and 1903, the activity occurred both on the south east and north rift zones, with eruptive fissures located on the axis of the rift zones associated with lava flows between 8 and $13 \mathrm{~km}$ long, reaching the eastern coast $(1848,1858,1862,1876$ and 1880) or the western coast (1858 and 1859). Only one lava emission occurred outside of the rift zone (1872), at the north-western foot of Karthala volcano, at about $250 \mathrm{~m}$ a.s.l., and also reach the western coast close to Vanamboini village.

2) During the second period, between 1904 and 1972, lava emission was localized only along the north rift zone (1904 and 1918), but the associated lava flows do not reached the sea as in the previous period. Eruptive activity also occurred inside the summit caldera, with a phreatic eruption inside the main eruptive crater, the Choungou Chahale (1918). The other eruptions were purely magmatic and located inside the main crater or inside the northern lobe of the caldera, constituting the extension of the north rift zone (see below). The 1977 eccentric magmatic eruption, near the western coast, with eruptive fissures at about $360 \mathrm{~m}$ 
a.s.l., and associated lava flows destroying part of Singani village, constitutes a transition toward the third period.

3) During the third period, between 1991 and the present, the activity was localized only in the summit caldera. A succession of three phreatic eruption, affecting in both cases a large part of Grande Comores inhabitants (evacuation of people by local authorities, water tank contamination, health problems due to the fine ash-falls, panic among the villagers; see Morin et al., 2016, Chapter 25), occurred in the Choungou Chahale crater, in July 1991, April 2005 and November 2005.

(a) The eruption of $11^{\text {th }}$ July 1991 was purely phreatic and proceeded by 7 days of intense seismicity (4000 earthquakes per day) and ended in less than $24 \mathrm{~h}$.

(b) Before the phreato-magmatic eruption of $16^{\text {th }}$ April 2005, an increase in the seismicity also occurred during the month of March with 40 earthquakes on average per day. The eruption of April 2005 lasted with an activity of active lava lake started on $17^{\text {th }}$ April and ended on $19^{\text {th }}$ April.

(c) At the end of August 2005, another period of greater seismicity began and resulted in another phreato-magmatic eruption on $24^{\text {th }}$ November 2005. This eruption evolved quickly $\left(25^{\text {th }}\right.$ November) in a lava lake activity which ended on $8^{\text {th }}$ December 2005 with two small cones with strombolian activity. This succession of three explosive eruptions, with a phreatic component, was trigged in both cases by the water lake present in the bottom of Choungou Chahale crater.

Thanks to the November 2005 eruption, the effusive activity inside Choungou Chahale crater was enough in term of thickness of lava lake to avoid the reappearance of the water lake at the bottom of the crater. As a consequence, the following eruption, which occurred inside the Choungou Chahale crater on $28^{\text {th }}$ May 2006, was purely magmatic. This eruption began after one week of higher seismicity (20 earthquakes per day between $20^{\text {th }}-27^{\text {th }}$ May 2006), was characterized by huge lava fountaining activity and ended on $31^{\text {st }}$ May 2006.

The last eruptive activity at Karthala volcano occurred on $13^{\text {th }}$ January 2007 , after an earthquake $(M>4)$ on $12^{\text {th }}$ January 2007 , felt by Grande Comores inhabitants. This eruption that lasted less than $24 \mathrm{~h}$, was purely magmatic and located only inside the Choungou Chagnoumeni crater (Bachèlery et al., 2016). 
During historical times, the most active area of the summit caldera was inside the Choungou Chahalé crater (1918, 1948, 1952, 1959?, 1991, April 2005, November 2005, May 2006; see Fig. 1c). Outside this crater, the other area of high level of activity is the northern lobe of the caldera associated with the most intense hydrothermal circulation (Lénat et al., 1998) and seismicity (Savin et al., 2005). Moreover, some eruptions occurred in this area; lava flow in 1965, scoria cones and aa lava flow in 1972 covering nearly the entire northern lobe of the caldera and overflowing to the north, and four eruptions of the Choungou Chagnoumeni pit crater $(1918,1948,1965$, and 2007), which is qualified for that of second active crater of Karthala. This latter, of about $225 \mathrm{~m}$ in diameter, with vertical walls, was formed during the 1918 phreatic eruption, which structured both the northern part of the present-day Choungou Chahale crater and the Choungou Chagnoumeni crater. From (1) a depth of about 150m in 1936 (after its formation in 1918), the Choungou Chagnoumeni crater was gradually infilled to (2) a depth of about 50-60m in 1952 during a magmatic activity of Choungou Chahale affecting Choungou Chagnoumeni pit crater, and (3) about 30m depth after the 1965 Choungou Chagnoumeni lava flow activity, and (4) only 7-8 $\mathrm{m}$ depth (7,26m exactly with average calculation from DEM's; Nicolas Villeneuve, personal communication) after the large magmatic eruption of 1972 refilling large part the northern lobe of the summit caldera (Bachèlery and Coudray, 1993; see Fig. 1d). The crater was the site of the $13^{\text {th }}$ January 2007 eruption, and was completely infilled in less than 24 hours by a volume of about $275,000 \mathrm{~m}^{3}$ of basaltic lava emitted from a NE-SW eruptive fissure located inside the Choungou Chagnoumeni crater (Bachèlery et al., 2016;). A line of spatter cones marks the eruptive fissure crossing the Choungou Chagnoumeni crater (see Fig. 1e). This lava can be likened to a rough surface pahoehoe lava flow. In this paper, we will use " $t_{0}$ " to talk about of the day of the eruption (13 ${ }^{\text {th }}$ January 2007). During the first mission in March 2008, the thickness of post-eruption sedimentary deposits, brought mainly by rainwater, in the studied area, was of about 25-30 cm, constituted of fine ash removed material (Figures $2 \mathrm{a}, 2 \mathrm{c}$ ). This fine sedimentary deposit allows performing good quality temperature and soil gas measurements, limiting both the cooling and the dilution with the air. Without this thickness of sedimentary deposits, temperature and soil gas measurements above the $13^{\text {th }}$ January 2007 rough pahoehoe lava flow would have been impossible, due to the too strong interaction (temperature and chemical dilution) with the air.

\section{Methods}

\subsection{Data acquisition and processing}


At $\mathrm{t}_{0}+420$ days (in March 2008), a Campbell Scientific datalogger (CR1000) with a multiplexor (AM25T) was installed close to the Choungou Chagnoumeni crater. After digging a trench, 11 temperature sensors (thermocouples $\mathrm{K}$ type) were placed at $30 \mathrm{~cm}$ depth along a straight profile, perpendicular to the western rim of the Choungou Chagnoumeni crater, beginning inside and at $1 \mathrm{~m}$ from the border toward the center of the crater (Figs. 2a, 2c). The spacing between each sensor is $1 \mathrm{~m}$. The CR1000 recorded 1 measurement per hour for each sensor. As a safety reason for the scientific equipment (vandalism), no solar panel has been installed and all the equipment was hidden under the ground (Fig. 2b). As a consequence, the data set was obtained during 4 periods of time, when the battery was changed:

(1) From $3^{\text {rd }}$ March 2008 to $5^{\text {th }}$ May 2008 (during 64 consecutive days),

(2) From $22^{\text {nd }}$ August 2008 to $23^{\text {rd }}$ October 2008 (during 63 consecutive days),

(3) From $15^{\text {th }}$ June 2009 to $18^{\text {th }}$ August 2009 (during 65 consecutive days),

(4) From $18^{\text {th }}$ October 2009 to $8^{\text {th }}$ January 2010 (during 83 consecutive days).

Hence, during the period $3^{\text {rd }}$ March $2008-8^{\text {th }}$ January 2010, 275 days out of 677, corresponding to more than $40 \%$ of this period, was monitored. No data was lost during the consecutive days of monitoring period when the battery was working. 


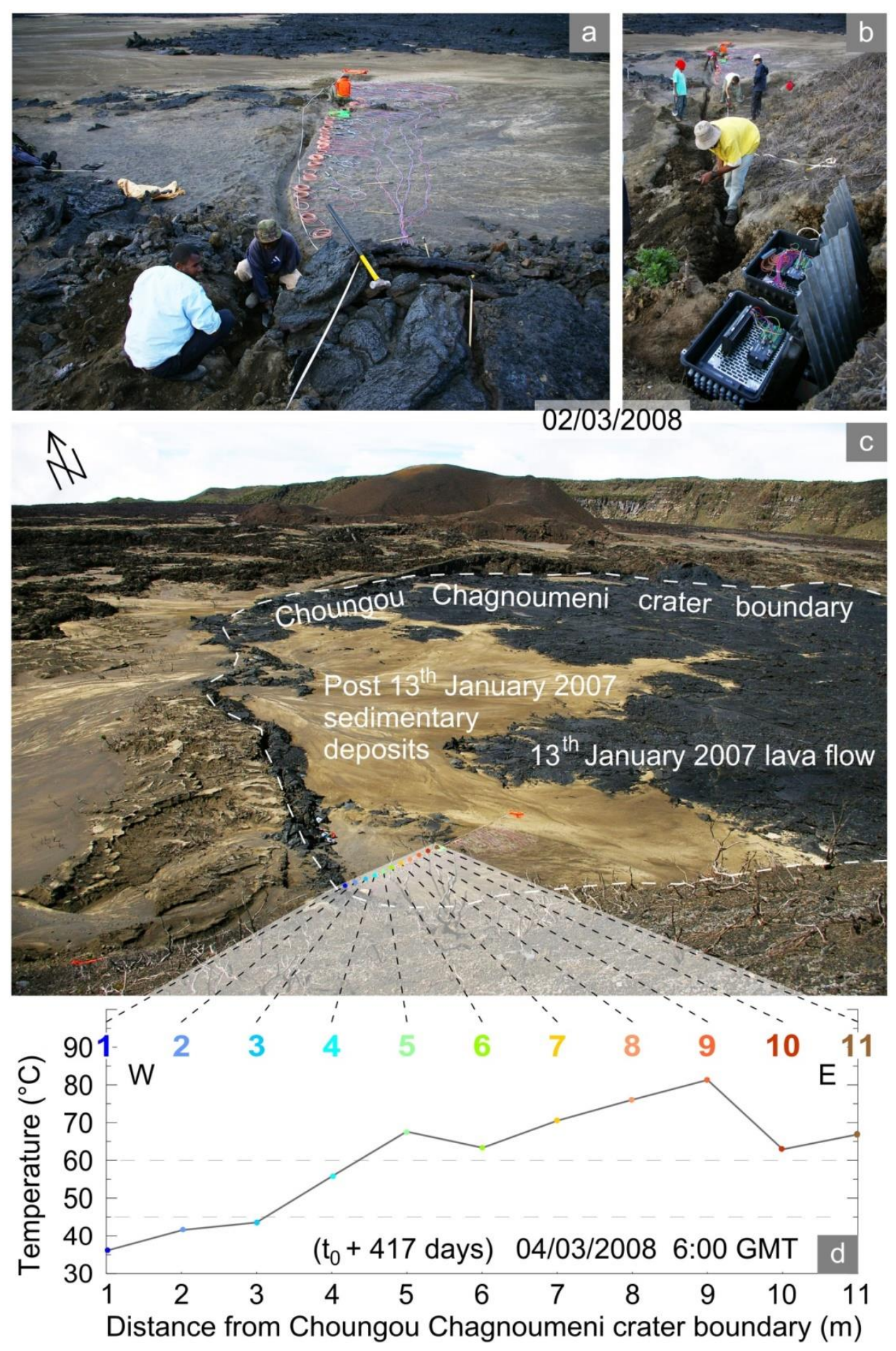

Figure 2: (a) Installation of the eleven temperature sensors at $30 \mathrm{~cm}$ depth inside the

Choungou Chagnoumeni crater; (b) Installation of the Campbell Scientific monitoring station outside the Choungou Chagnoumeni crater; (c) Large view picture showing the location of the eleven temperature sensors located inside the Choungou Chagnoumeni crater; (d)

Temperature of the eleven sensors measured at $30 \mathrm{~cm}$ depth, two days after the installation. The dashed lines link the bottom temperature plot abscissa (figure d) to the position of the sensors on the photography (figure c). 
On $4^{\text {th }}$ March 2008 at 6:00 GMT, the second day of monitoring (corresponding to $t_{0}+417$ days), we can note at $30 \mathrm{~cm}$ depth a clear lateral temperature gradient from less than $40^{\circ} \mathrm{C}$ up to more than $80^{\circ} \mathrm{C}$, increasing globally toward the center of the crater (Fig. $2 \mathrm{~d}$ ). This result is in good accordance with the original source of heat; the lava flow located inside the Choungou Chagnoumeni crater.

Moreover, at $\mathrm{t}_{0}+884$ days (in June 2009 and during the third monitoring period), we performed above the monitoring sensors, an electrical resistivity tomography (ERT) survey coupled with soil $\mathrm{CO}_{2}$ concentration measurements.

ERT data were obtained using a set of 64 stainless steel electrodes with 2 meters spacing between the electrodes, the ABEM Terrameter SAS-4000 resistivity meter and ES1064 multiplexer. The contact of the electrodes with the ground was improved by adding salty water.

A unique profile of $126 \mathrm{~m}$ long (63 spacings between 64 electrodes with $2 \mathrm{~m}$ spacing between take-outs) was performed positioning the middle of the profile, just on the western rim of the Choungou Chagnoumeni crater (Fig. 2c).

A Wenner alpha array was setup both for the good signal-to-noise ratio and the good sensitivity for the detection of vertical changes in the subsurface resistivity below the centre of the electrode array. For each acquired measurement, we performed stacking to get a standard deviation better than 5 per cent with a maximum of 4 stacks.

A good contact resistance between electrodes and medium allowed injecting a maximum of $200 \mathrm{~mA}$ current.

We acquired a total of 472 measurements of apparent resistivity. Topography is totally flat along our profile. The ERT data were then inverted by means of the commercial package RES2DINV (Loke and Barker, 1996) using a finite element grid for the forward modeling of the apparent resistivity. The RMS error obtained after 5 iterations is 6.1 per cent. Resistivity tomogram is shown in Fig $3 b$. 

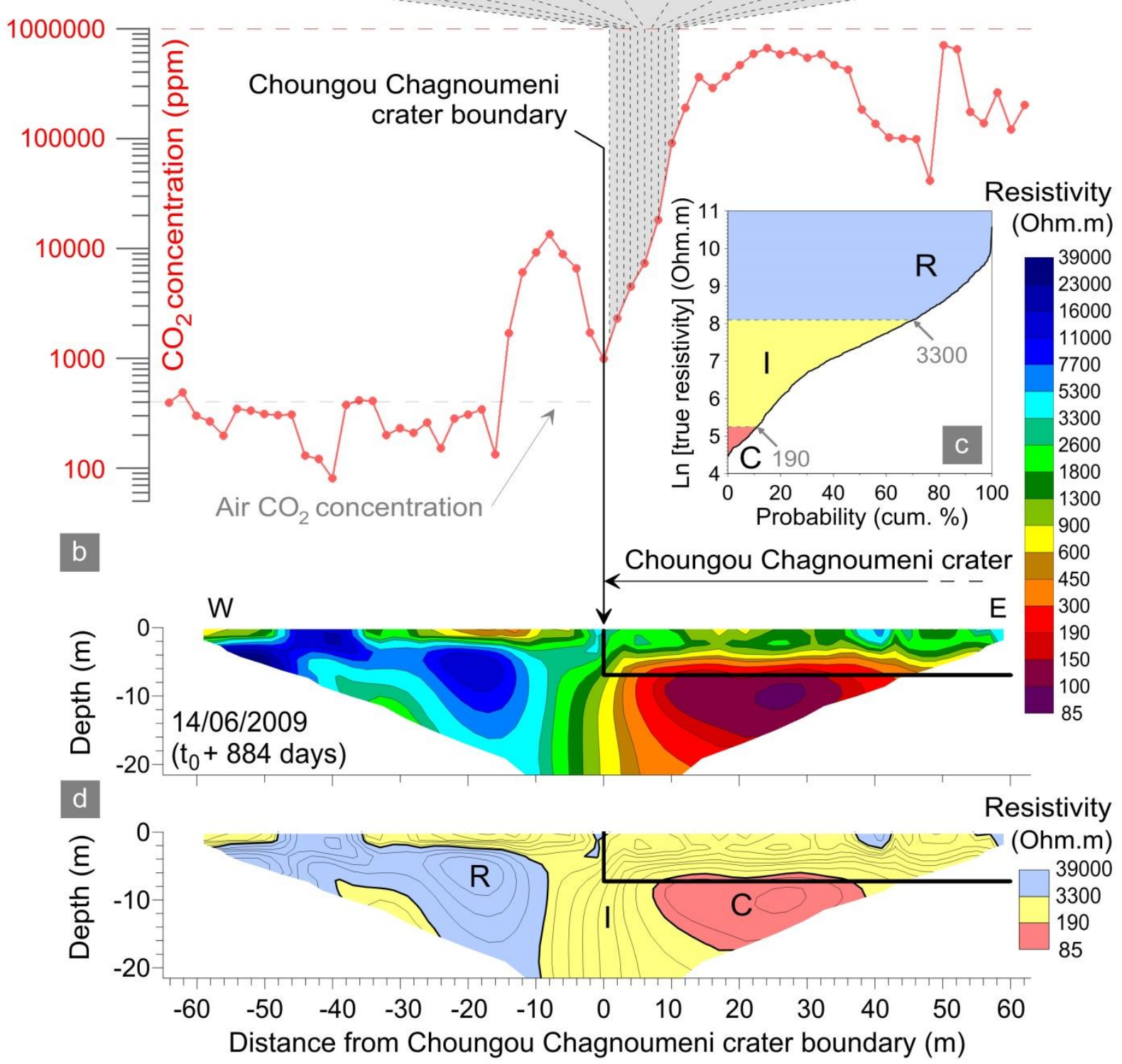

Figure 3: (a) Soil $\mathrm{CO}_{2}$ concentration profile crossing the rim of the Choungou Chagnoumeni crater; (b) Electrical resistivity tomography (ERT) profile crossing the rim of the Choungou Chagnoumeni crater; (c) Probability plot analysis (Sinclair, 1974) of the true resistivity values measured on the ERT profile; (d) Electrical resistivity tomography (ERT) profile showing the three ranges of resistivity values identified through the probability plot technique. "R", "I" and "C" stand for Resistant, Intermediate and Conductive body, respectively. 
In addition to 2-D DC-resistivity tomography, we also acquired contemporaneously, soil $\mathrm{CO}_{2}$ concentration measurements. These measurements were obtained with a spacing of $2 \mathrm{~m}$ along the profile, taking measurements in correspondence with all the ERT electrodes.

Soil gas was sampled through a copper tube ( $2 \mathrm{~mm}$ in diameter). This copper tube was first inserted in the soil to a depth of $0.5 \mathrm{~m}$. The gas was analyzed directly in the field by infrared spectrometry (Edinburgh Instruments, model GasCheck). The analytical uncertainty was 5 per cent of the concentration value (see Revil et al., 2011). The $\mathrm{CO}_{2}$ concentration profile is shown in Fig 3a.

\subsection{Numerical method}

The cooling of lava flow has been modeled in different context. Shaw et al. (1977) produced one of the first numerical formulations to model the cooling of lava lakes. They solved the heat balance equation in one-dimension by a method of explicit cell balances using a stack of elements. A temperature of $0^{\circ} \mathrm{C}$ is fixed at the top of the stack and $1000^{\circ} \mathrm{C}$ is given for the initial temperature of magma. The heat loss occurs by conduction and by adding two source functions for the latent heat of crystallization and for the vaporization of the rain. Peck et al. (1977) applied these numerical formulations on the specific case of the Alae lava lake from Hawaii which provides good results compare to the observations. Thereafter, many authors have studied and quantified by analysis and observations the main heat transfer mechanisms with the atmosphere: radiation, natural convection and forced convection by the wind (see Head and Wilson, 1986; Keszthelyi, 1995; Keszthelyi et al., 2003). Keszthelyi and Denlinger (1996) have developed a numerical model for the initial cooling of pahoehoe lobes taking into account the conduction, the thermal radiation, the forced and free convection and the latent heat of crystallization. Their formulation is based on a fully explicit finite-difference algorithm. Neri (1998) has developed another formulation based on an original application of the integral heat balance method (Goodman, 1964; Ozisik, 1993). The model involves radiation, forced or natural convection. It also taking into account the crystallization and the formation of crust layer at the surface where the thermal properties can be different than the mushy layers one. Equations are numerically solving by ordinary differential equations, in terms of surface temperature and by a Runge-Kutta method in the crust and mushy layer thicknesses. Other articles deal with the effect of the cooling on the dynamic of a lava flow (see Danes, 1972; Dragoni, 1989; Harris and Rowland, 2001; Bernabeu et al., 2016; Chevrel et al., 2018). 


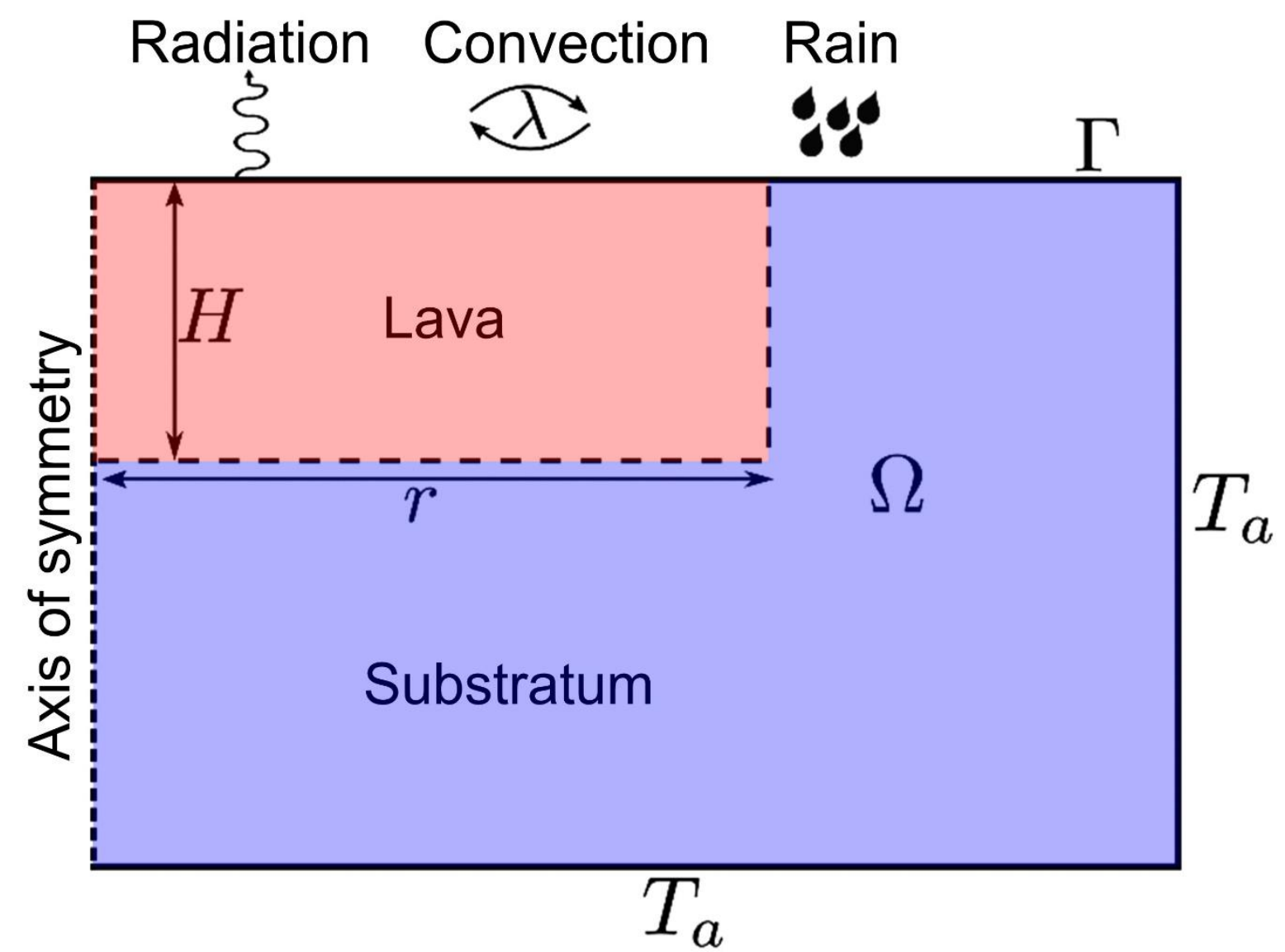

Figure 4: Representation of the geometrical model used for the numerical modeling with the Rheolef software: the calculation domain $\Omega$ occuped by the lava and the substratum at the center; the interface $\Gamma$ between $\Omega$ and the atmosphere with the different heat flux on the top; the axis of symmetry on the left and the ambient-imposed temperature condition at the bottom and on the right.

Note that all codes presented in section 2.2 which all based on a explicit time schemes and uniform spatial grids. From one hand, we choose here to use an implicit scheme, since it is more robust for long time simulations. From other hand, we choose to base our computations on non-uniform spatial grids, suitable to take into account a large substratum region. So, we decided to write a code based on the finite element $\mathrm{C}++$ library Rheolef for our numerical model of the Choungou Chagnoumeni cooling. Using the cylindrical symmetry of the geometry, the calculation domain $\Omega$ is reduced to a vertical radial plane cut (see Fig. 4). It is composed in two parts: the crater occupied by the lava with a radius $r$ and a depth $H$ and the substratum. To avoid the boundary effect, we choose for the numerical simulation a substratum region with a size of 20 times the thickness of the deposit (145.2 m). The evolution of the temperature $T$ inside $\Omega$ is model for all time $t>0$ by the heat equation using the Fourier's law conduction and a source term coming from the latent heat of crystallization: 


$$
\rho C_{p} \frac{\partial T}{\partial t}-\operatorname{div}(\lambda \nabla T)=L \frac{\partial \phi}{\partial t} \text { in } \Omega
$$

where $\rho$ is the lava density considering the porosity and determined from the densities of the various lava flow levels (see Deroussi et al., 2009), $C_{p}$ the heat capacity, $\lambda$ the diffusion, $L$ the latent heat of crystallization and $\phi$ the crystallinity (i.e. the solid volume fraction). The numerical value of $L$ has been taken in Chevrel et al (2018).

We assume as in Huber et al., 2009 that the crystallinity depends only of the temperature by the relationship

$$
\begin{gathered}
\phi=\frac{T_{\text {liq }}-T}{T_{\text {liq }}-T_{\text {sol }}} \text { for } T_{\text {sol }}<T<T_{\text {liq }}, \\
\phi=1 \text { for } T<T_{\text {sol }} \text { and } \phi=1 \text { for } T>T_{\text {liq }},
\end{gathered}
$$

where $T_{\text {liq }}$ is the liquidus temperature and $T_{\text {sol }}$ the solidus temperature. The value of $T_{\text {liq }}$ has been taken in Dragoni, 1989 and the value of $T_{\text {sol }}$ in Chevrel et al., 2018.

The model incorporates at the interface $\Gamma$ between $\Omega$ and the atmosphere the radiative flux, the convective flux and the heat flux to warm up and vaporize the rain (see Fig. 4). Indeed, we suppose that the vaporization of rain is only located in surface and we neglect the water infiltration, the vaporization in depth and the rise of the vapor. Thereby, when the surface temperature is less than the vaporization temperature $\left(100^{\circ} \mathrm{C}\right)$, the rain has no more effect on the cooling except the water heater. The air conduction (0,0262 W.m.K; see Adrian and Allan, 2003 ) is extremely small and will be neglected.

$$
-\kappa \frac{\partial T}{\partial n}=q_{r a d}+q_{c o n v}+q_{v a p} \text { on } \Gamma,
$$

where:

$$
q_{\text {rad }}=\varepsilon \sigma\left(T^{4}-T_{a}^{4}\right),
$$




$$
\begin{gathered}
q_{c o n v}=h_{c}\left(T-T_{a}\right), \\
q_{v a p}=\rho_{e} p_{e}\left(C_{p, e}\left(T_{v a p}-T_{a}\right)+L_{e}\right), \text { for } T \geq T_{v a p}, \\
q_{v a p}=\rho_{e} p_{e} C_{p, e}\left(T-T_{a}\right), \text { for } T<T_{v a p},
\end{gathered}
$$

where $n$ is the unit outward vector of $\Gamma, \varepsilon \in[0,1]$ the emissivity which increases to one when the lava turns black, $\sigma$ the Stefan-Boltzmann constant, $T_{a}$ the ambient temperature (using also as the rain temperature), $h_{c}$ the coefficient of heat transfert by convection which is between 5 and $25 \mathrm{~W} \cdot \mathrm{m}^{-2} \cdot \mathrm{K}^{-1}, \rho_{e}$ the density of water, $C_{p, e}$ the heat capacity of water, $L_{e}$ the latent heat of change of liquid-water vapor at the temperature $T_{v a p}$ and $p_{e}$ the rainfall inside the Choungou Chagnoumeni crater (expressed in meters per year).

The value of $10 \mathrm{~m}_{\mathrm{yr}} \mathrm{r}^{-1}$ of rainfall inside the Choungou Chagnoumeni crater has been calculated thanks to the bibliographical data. The highest rainfall values recorded near the coast, at the foot of Karthala volcano is of $5888 \mathrm{~mm} / \mathrm{yr}$ (western part of Nioumbadjou town; Frenken, 2005). Using an altitudinal gradient of $120 \mathrm{~mm} / 100 \mathrm{~m}$ (Brouwers, 1973), we obtain on the caldera floor of Karthala volcano, at $2260 \mathrm{~m}$ a.s.1., an increase of about $2712 \mathrm{~mm}$ respect to the coast, reaching therefore a value of $8600 \mathrm{~mm} / \mathrm{yr}$. Considering that (1) the altitudinal gradient of $120 \mathrm{~mm} / 100 \mathrm{~m}$ proposed by Brouwers (1973) seems to be underestimated (Mirhani, 2014) and that (2) during the highest rainfall events, the Choungou Chagnoumeni crater receive water (and sediments) from outside the Choungou Chagnoumeni crater boundary, due to the funnel shape of part of the external crater environment (see Fig. 2c), we therefore consider for the model the value of $10 \mathrm{~m} / \mathrm{yr}$ of rainfall inside the Choungou Chagnoumeni crater; the bottom of the crater being flat. In order to avoid any kind of major uncertainties induced by the lack of rainfall data on the top of Karthala volcano, the heat flux lost by the rainfall events will be then discussed compared to the other cooling phenomenon.

The value of $15^{\circ} \mathrm{C}$ of ambient temperature $T_{a}$ has been calculated as an annual average of the Karthala temperature provided by the National Centers for Environmental Information (https://www.ncdc.noaa.gov/).

A condition of symmetry is given along the axis of symmetry and the ambient temperature is imposed along the external boundaries of the substratum (Fig. 4). The initial temperature on 
$\Omega$ is given by a temperature $T_{0}$ in the lava domain and an ambient temperature $T_{a}$ in the substratum. The Table 1 resumes all the physical values used for computation.

Table 1: Physical values and units used for the numerical modeling.

\begin{tabular}{|c|c|c|}
\hline Physical value & Value & Unit \\
\hline$\rho$ & 2200 & $\mathrm{~kg} \cdot \mathrm{m}^{-3}$ \\
\hline$C_{p}$ & 1225 & $\mathrm{~J} \cdot \mathrm{kg}^{-1} \cdot \mathrm{K}^{-1}$ \\
\hline$\lambda$ & 2 & J. $\mathrm{s}^{-1} \cdot \mathrm{m}^{-1} \cdot \mathrm{K}^{-1}$ \\
\hline$\varepsilon$ & 0.95 & - \\
\hline$\sigma$ & $5.6704 \times 10^{-8}$ & $\mathrm{~W} \cdot \mathrm{m}^{-2} \cdot \mathrm{K}^{-4}$ \\
\hline$h_{c}$ & 10 & $\mathrm{~W} \cdot \mathrm{m}^{-2} \cdot \mathrm{K}^{-1}$ \\
\hline$\rho_{e}$ & 1000 & $\mathrm{~kg} \cdot \mathrm{m}^{-3}$ \\
\hline$C_{p, e}$ & 4180 & $\mathrm{~J} . \mathrm{kg}^{-1} \cdot \mathrm{K}^{-1}$ \\
\hline$L_{e}$ & $2.257 \times 10^{6}$ & J.kg-1 \\
\hline$T_{a}$ & 288 & $\mathrm{~K}$ \\
\hline$T_{0}$ & 1473 & $\mathrm{~K}$ \\
\hline$T_{\text {vap }}$ & 373 & $\mathrm{~K}$ \\
\hline$p_{e}$ & 10 & $\mathrm{~m} \cdot \mathrm{yr} \mathrm{r}^{-1}$ \\
\hline$H$ & 7.26 & $\mathrm{~m}$ \\
\hline$r$ & 112.5 & $\mathrm{~m}$ \\
\hline$L_{l i q}$ & 1473 & $\mathrm{~K}$ \\
\hline$L_{\text {sol }}$ & 1250 & $\mathrm{~K}$ \\
\hline$L$ & $3.5 \times 10^{5}$ & J.kg-1 \\
\hline
\end{tabular}

\section{Results}

\subsection{ERT and $\mathrm{CO}_{2}$ results}

We first begin to comment, on a structural point of view, the $\mathrm{CO}_{2}$ concentration and ERT straight profile performed from both sides of the western Choungou Chagnoumeni crater boundary, on $14^{\text {th }}$ June $2009\left(\mathrm{t}_{0}+884\right.$ days $)$.

The $\mathrm{CO}_{2}$ concentration profile allow to perfectly identify the limit of Choungou Chagnoumeni crater, with a sharp lateral increase in the $\mathrm{CO}_{2}$ concentration, from values close to air $\mathrm{CO}_{2}$ concentration ( $\left.400 \mathrm{ppm}\right)$ up to $200,000 \mathrm{ppm}$, in less than 15 meters (Fig. 3a). Such high $\mathrm{CO}_{2}$ values, reaching more than $70 \%$, display a clear degassing activity still in progress inside the Choungou Chagnoumeni crater, more than 2 years after the effusive activity, and a good permeability between the source and the surface inside the Choungou 
Chagnoumeni crater. However, it is not possible to say if the degassing source is related to the cooling of the lava flow or to a deeper magmatic source. It is also interesting to note that at the boundary of Choungou Chagnoumeni crater and with a radius of influence of $8 \mathrm{~m}$ the $\mathrm{CO}_{2}$ values are decreasing, with a minimum of $\mathrm{CO}_{2}$ concentration located just on the boundary of Choungou Chagnoumeni crater (Fig. 3a). This decreasing of $\mathrm{CO}_{2}$ concentration is probably related with higher permeability values located on the structural boundary of the crater, as we will discuss after.

About ERT results, the structural boundary with a right angle, formed by the bottom and the edge of the Choungou Chagnoumeni pit crater (thick black line in figure 3b), is associated only partially with a transition of resistivity. At about 7 meter depth, a lateral resistivity transition exist; with values in the range 1,800-16,000 Ohm.m (green-blue color) outside the Choungou Chagnoumeni crater, and with values in the range 1,300-150 Ohm.m (yelloworange-red color) inside the Choungou Chagnoumeni crater. It is very important to note that this lateral resistivity transition reach the depth of about 20 meters (limit depth of the tomography), but 1) it is a gradual transition and not a drastic one, and 2) it do not reach the surface. Indeed, between 0 and about 3 meter depth, there is no significant lateral transition in resistivity. That means that the petrological changes between the inner and the external part of the Choungou Chagnoumeni crater (refilled or not by the recent lava flow of January $13^{\text {th }}$ 2007) is not directly involved in this lateral change of resistivity. We will talk about this topic in the Discussion section.

\subsection{Numerical results}

The results of the thermal modeling are shown in Fig. 5. Four different steps of cooling have been chosen:

(1) The initial thermal conditions ( $\mathrm{t}_{0}$ : Fig. 5a),

(2) The thermal propagation after 1 year $\left(t_{0}+365\right.$ days: Fig. $\left.5 b\right)$,

(3) The thermal propagation after 2 years $\left(t_{0}+730\right.$ days: Fig. $\left.5 c\right)$,

(4) The thermal propagation after 3 years $\left(t_{0}+1095\right.$ days: Fig. $\left.5 d\right)$. 

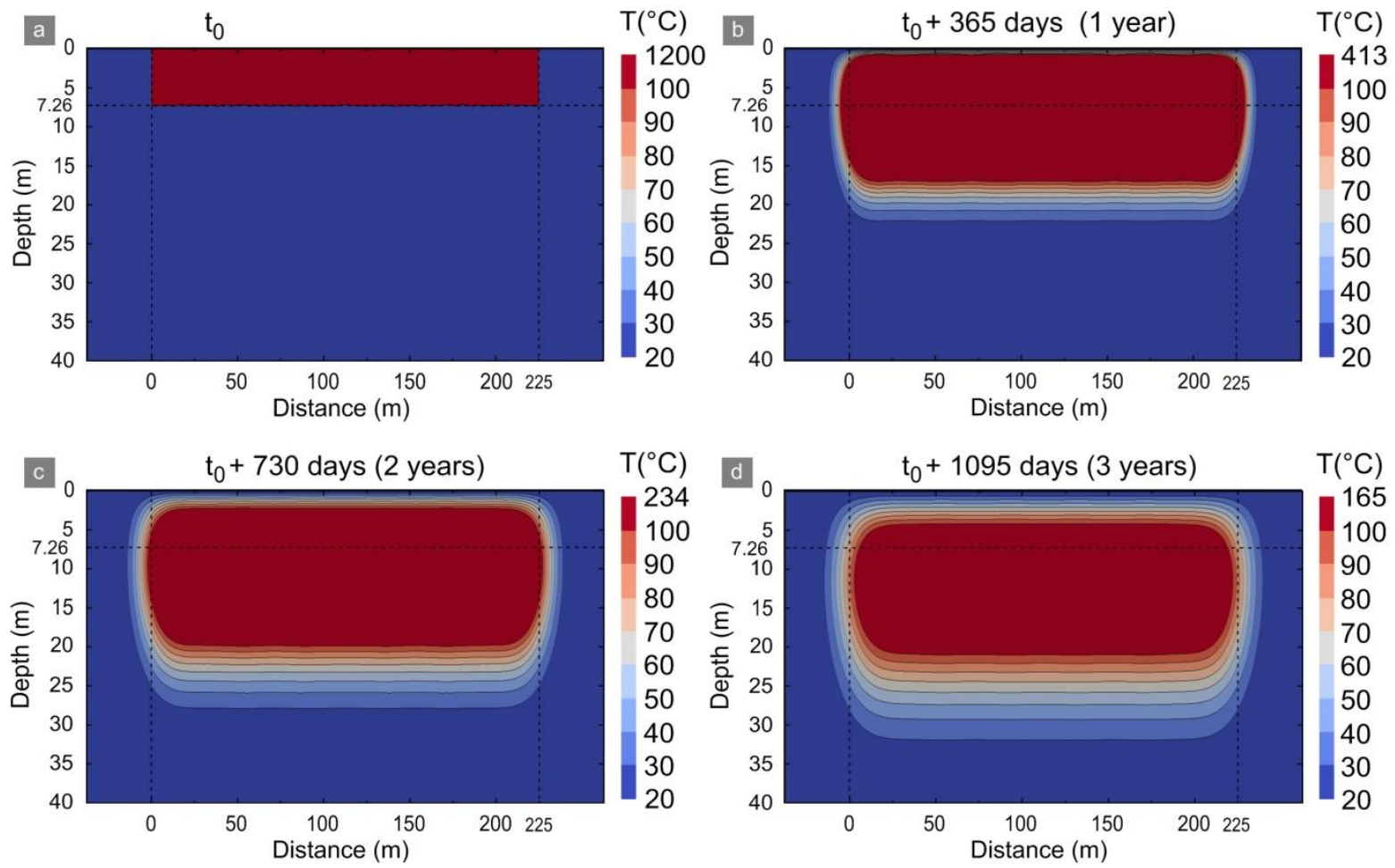

Figure 5:2D results obtained with the numerical modeling for the temperature of the lava

flow cooling inside the Choungou Chagnoumeni crater (a) at $\mathrm{t}_{0}$; (b) at $\mathrm{t}_{0}+1$ year; (c) at $\mathrm{t}_{0}+2$ years; (d) at $\mathrm{t}_{0}+3$ years.

It is interesting to precise that from an initial condition of liquid lava with a homogeneous temperature of $1200^{\circ} \mathrm{C}\left(\mathrm{T}_{0}\right)$, the maximum of temperature remaining, with the temperature modeling is of:

(1) $413^{\circ} \mathrm{C}$ at $7.26 \mathrm{~m}$ depth after 1 year of magma cooling,

(2) $234^{\circ} \mathrm{C}$ at $10.16 \mathrm{~m}$ depth after 2 years of magma cooling, and

(3) $165^{\circ} \mathrm{C}$ at $12.14 \mathrm{~m}$ depth after 3 years of magma cooling.

For readability reasons, we decided to represent in the four figures shown in Fig. 4 only the isotherms of $30,40,50,60,70,80,90$ and $100^{\circ} \mathrm{C}$, considered to be the most interesting for our study.

In Fig. 6b, we represent the temperature of the 11 sensors located at $30 \mathrm{~cm}$ depth and spaced 1 meter apart (see location in Fig. 2c) collected by the Campbell Scientific datalogger during the four monitoring periods, superimposed with the modeled temperature and extracted from 11 points, located at the same place of the temperature sensors. 

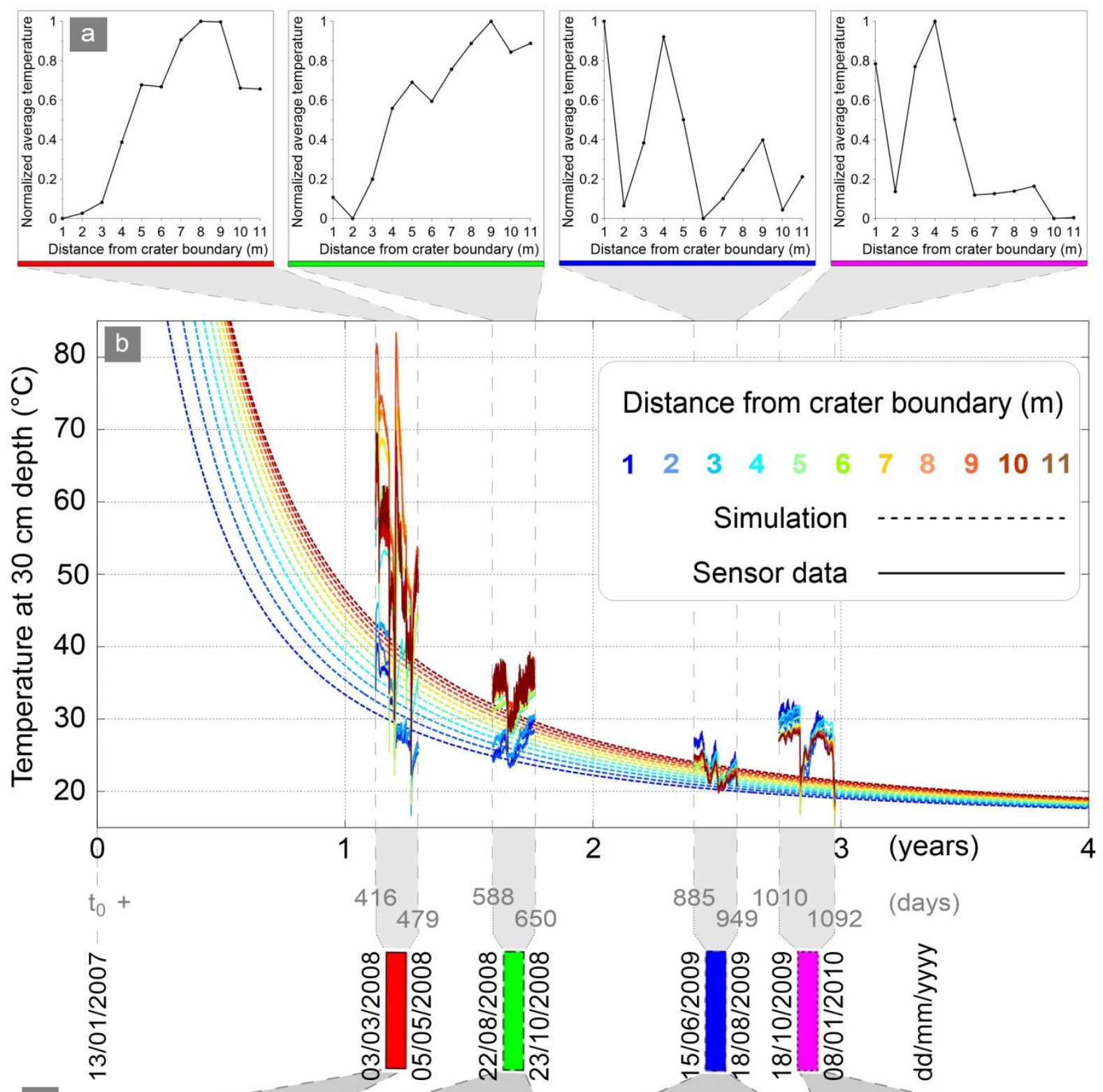

c _._. Time from effusive activity (years, days or date)

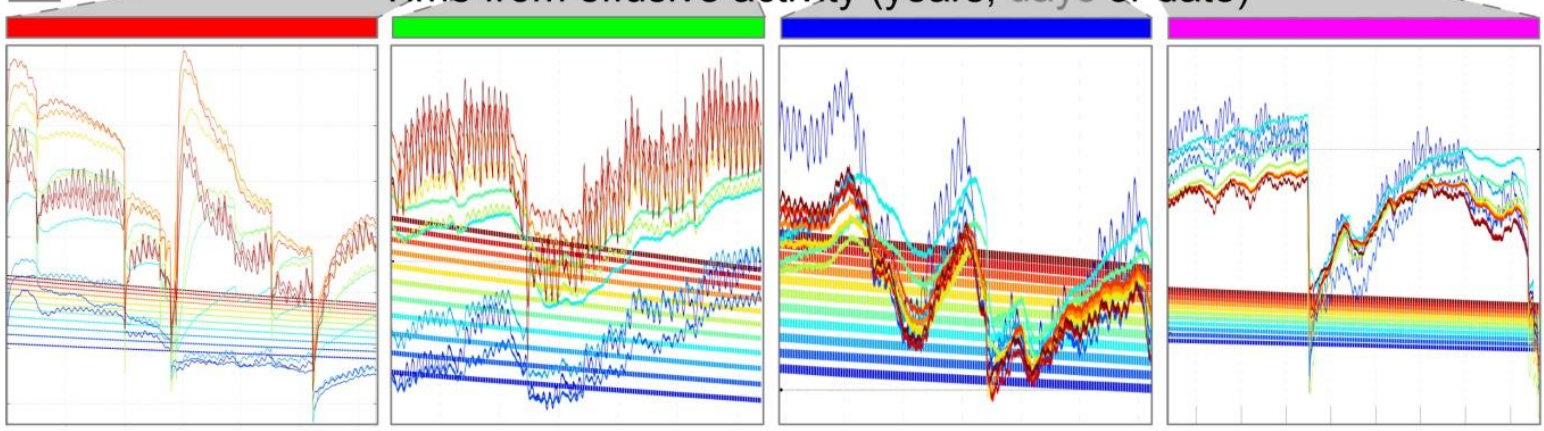

Figure 6: (a) Normalized average temperature for each one of the eleven sensors, for the 4 periods of monitoring; (b) Temperature measured and modeled, at $30 \mathrm{~cm}$ depth, for the eleven sensors located inside the Choungou Chagnoumeni crater. 
Data collected from our CR1000 display sharp temperature variation in time for the 11 sensors. These variations are mainly related with raining events (Gaudin et al., 2015, 2017). Although these sharp temperature variations measured are not modeled, because the raining cooling impact ( $\sim 10 \mathrm{~m} / \mathrm{yr}$ ) is integrated in the model over all the year, it is interesting to note that the trend of cooling modeled is in good accordance with the temperature data monitored in the field.

For the first and the fourth monitored period, the temperature data from the sensors are significantly higher than the temperature modeled, which is not the case for the second and third monitored period which is better matching with the modeled data. This shift between the data and the modeled temperature could be attributed to the raining events. Indeed, for the Comoros archipelago and more specifically the Grande Comore island, the raining season encompasses December up to April (https://climate-data.org); the first and the fourth monitored periods are both located, in part, during the raining season, while the second and the third monitored period are clearly registering data only during the dry season. During strong raining events, the huge input in water infiltration inside the ground is responsible for the heating of the soil at shallow depth due to the vaporization of the raining water at few meter depth (Barde-Cabusson et al., 2009b). Conversely, in the model, the precipitations have few effects on the global thermal flux balance. Its influence, are always less than $1 \%$, as shown on Fig. 7, which represents the contribution of each surface thermal flux.

The differences between the data and the numerical code are related to different parameters. The shallow depth of the sensors $(30 \mathrm{~cm}$ depth) exposes the sensors to higher fluctuations forced by external parameters (e.g., strong raining events in a short period of time not considered in the modeling). Moreover, the presence of sensors close to a structural boundary allows determining convective phenomenon, with rising of vapor, due to variation of lateral permeability, as it will be discussed later, but not considered in the numerical code. These aspects can explain the discrepancy between the field data and the model. 


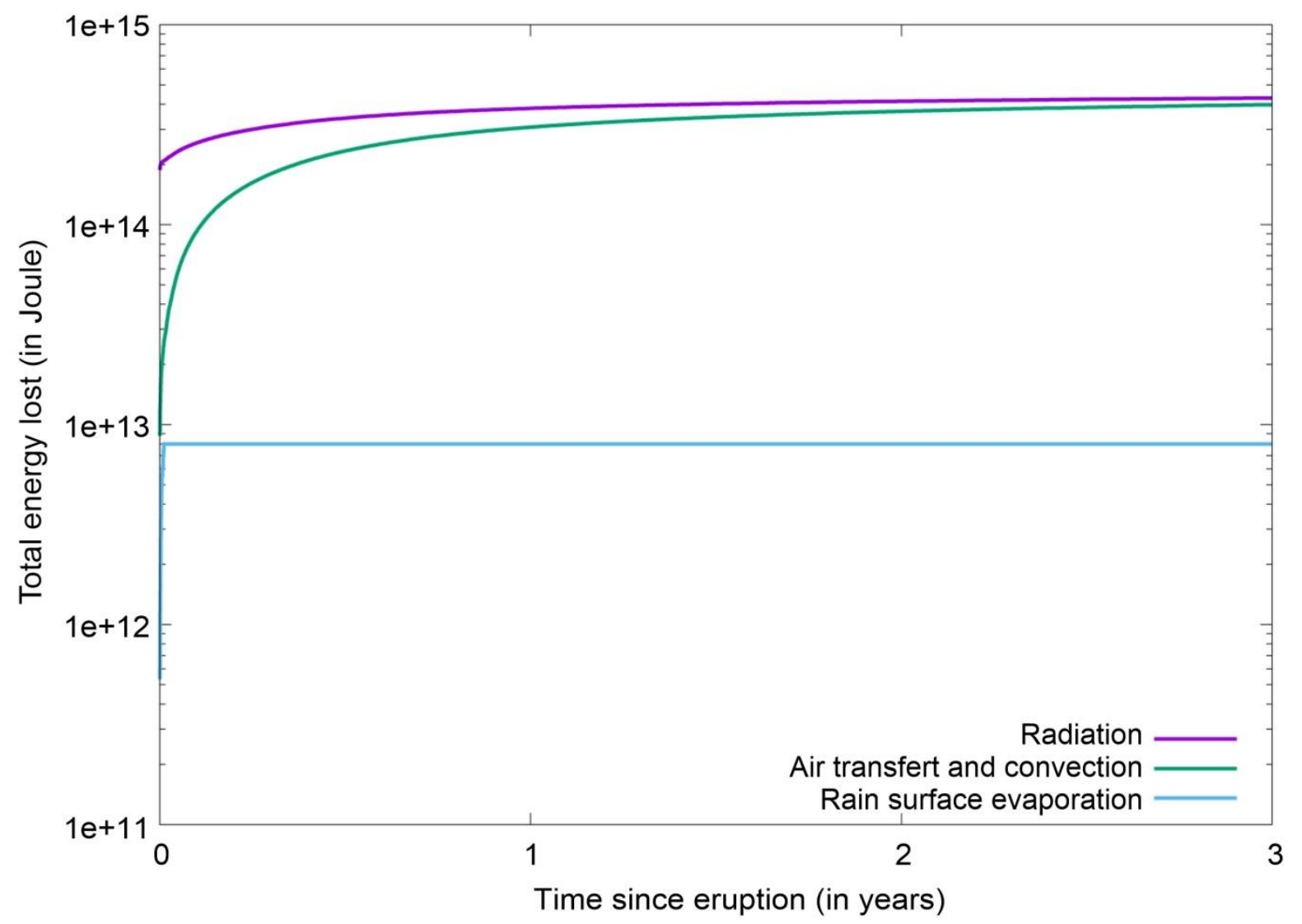

Figure 7: Contribution of each energy lost (from radiation, convection at the interface soilatmosphere and evaporation of rain) over time.

About the data monitored in the field, these latter display a surprising result: During the two first periods of monitoring ( $\mathrm{t}_{0}+416$ days up to $\mathrm{t}_{0}+479$ days and $\mathrm{t}_{0}+588$ days up to $\mathrm{t}_{0}+650$ days), the temperature recorded a lateral gradient increasing with the distance from the crater boundary (sensors $n^{\circ} 7$ to 11 (yellow-orange-red-brown colors) are the sensor of highest temperature; see Fig. 6). This result has been already presented for the first temperature measured with these sensors (Fig. $2 \mathrm{~d})$. During the last two periods of monitoring $\left(\mathrm{t}_{0}+885\right.$ days up to $t_{0}+949$ days and $t_{0}+1010$ days up to $t_{0}+1092$ days), the spatial temperature gradient is reversed, and the highest temperature appear close to the crater boundary. Note that only the four first sensors, closer to the crater boundary (blue color) are affected by this inversion (see zoom in Fig. 6c). Although temporal variations (mainly forced by the strong raining events) are of higher amplitude of spatial variations, these latter are clearly significant (Fig. 6c). 
This inversion of the temperature gradient have been also seen for the four periods of monitoring, taking into account for each sensor an average of all the measured temperature, normalized between 0 and 1. The inversion in the temperature gradient is also shown in Fig. 6a. Such inversion in the lateral temperature gradient is not visible on the modeled temperature and must be explained by an influence of the structural boundary not considered in the model (Fig. 6b).

Both ERT and temperature variations display surprising results; (1) in term of apparent incoherency between the spatial distribution of the resistivity values and the evident structural boundaries of the Choungou Chagnoumeni crater and (2) regarding the inversion in time, at more than two years from the effusive activity, in the shallow lateral temperature gradient.

These two aspects, dealing respectively with spatial and temporal problematic are discussed in the following session.

\section{Discussion}

\subsection{Spatial distribution of the resistivity values}

We first focus our discussion on the ERT profile performed on $14^{\text {th }} \mathrm{June} 2009$, so at $\mathrm{t}_{0}+884$ days from the effusive activity.

The most intriguing result for ERT profile is to not be able to recognize the shape of the Choungou Chagnoumeni crater. Indeed, several examples of crater boundaries on active volcanoes have been perfectly evidenced laterally and at depth using 2D ERT profiles (e.g. the NeoStromboli crater boundary on Stromboli volcano in Finizola et al., 2006 and Revil et al., 2011; or the Gran cratere on La Fossa cone of Vulcano island in Revil et al., 2008 and Barbe-Cabusson et al., 2009).

In order (1) to understand the meaning of the ERT profile obtained through the western border of the Choungou Chagnoumeni crater and (2) to know the values of resistivity corresponding to a transition in the ERT profile, we treated the true resistivity data with the probability plot technique (Sinclair, 1974). This statistical data processing, frequently used for diffuse 
degassing mapping to know how many sources are responsible at depth of the degassing values measured at the surface (Chiodini et al., 1998; 2001), has been also used on ERT profiles to identify the geological boundary between pre-Pliocene carbonatic bedrock and refilling plio-quaternary alluvial deposits (see supplementary material in Pucci et al., 2016). With our ERT data set, the probability plot technique (Fig. 3c) displays a typical three range of resistivity values (three asymptotic tendencies) subdivided by two points of inflection (see similar example of three lognormal populations subdivided by two inflection points; figure 5 in Sinclair, 1974). The two inflection points, inferred graphically, correspond to resistivity values of 3,300 and $190 \mathrm{Ohm} . \mathrm{m}$. These values correspond statistically to a transition between three groups of resistivity range: (1) lower than 190 Ohm.m., (2) between 190 and 3,300 Ohm., and (3) higher than 3,300 Ohm. The spatial distribution of these three ranges of resistivity values, defined from the probability plot technique is shown in Fig 3d. Three distinct areas can be evidenced. They have been noted with the letters "C", "I" and "R", corresponding respectively to "Conductor", "Intermediate" and "Resistive" body. Although the probability plot technique do not allowed understanding why the structural boundary of the Choungou Chagnoumeni crater is totally invisible on the ERT profile, it allowed to simply the ERT profile mainly into three areas "C", "I" and "R":

"C" is located below of the Choungou Chagnoumeni crater. The top of "C" begin at about $7 \mathrm{~m}$ depth and the western extension of "C" is also located at about $7 \mathrm{~m}$ from the western boundary of the Choungou Chagnoumeni crater.

From both side of the western boundary of the Choungou Chagnoumeni crater, from the surface up to more than $20 \mathrm{~m}$ depth, the area is occupied by "I". We can clearly note that the isopotential lines of "I" surround "C", suggesting a link between the source genesis of "C" and "I".

" $\mathrm{R}$ " is located only outside the western boundary of the Choungou Chagnoumeni crater at about $10 \mathrm{~m}$ from this crater. Note also the narrow vertical resistive body between the surface and about $3 \mathrm{~m}$ depth, located just at the boundary of the Choungou Chagnoumeni crater. In order to better understand the significance of the ERT profile, we compare the ERT results with the cooling model of the $13^{\text {th }}$ January 2007 lava flow that refilled the Choungou Chagnoumeni crater.

Using the Rheolef code, we stopped the temperature propagation at $\mathrm{t}_{0}+884$ days in order to compare the modeled temperature in the vertical section of the ground (Fig. 8a) with the distribution of the main ranges of electrical resistivity defined thanks to the probability plot 
technique (Fig. 8b). After $\mathrm{t}_{0}+884$ days, the maximum of temperature is $198^{\circ} \mathrm{C}$ and it is located at $10,85 \mathrm{~m}$ depth. The superimposition of the boundary subdividing the conductive, intermediate and resistive body (respectively "C", "I" and "R" in Fig. 8b) with the modeled temperature display an clear correlation (Fig. 8c); the boundary of " $\mathrm{C}$ " is centered inside the isotherm $100^{\circ} \mathrm{C}$, and the boundary of " $\mathrm{R}$ " seems to coincide with the lateral influence of the thermal propagation, between the isotherms 40 and $50^{\circ} \mathrm{C}$. 


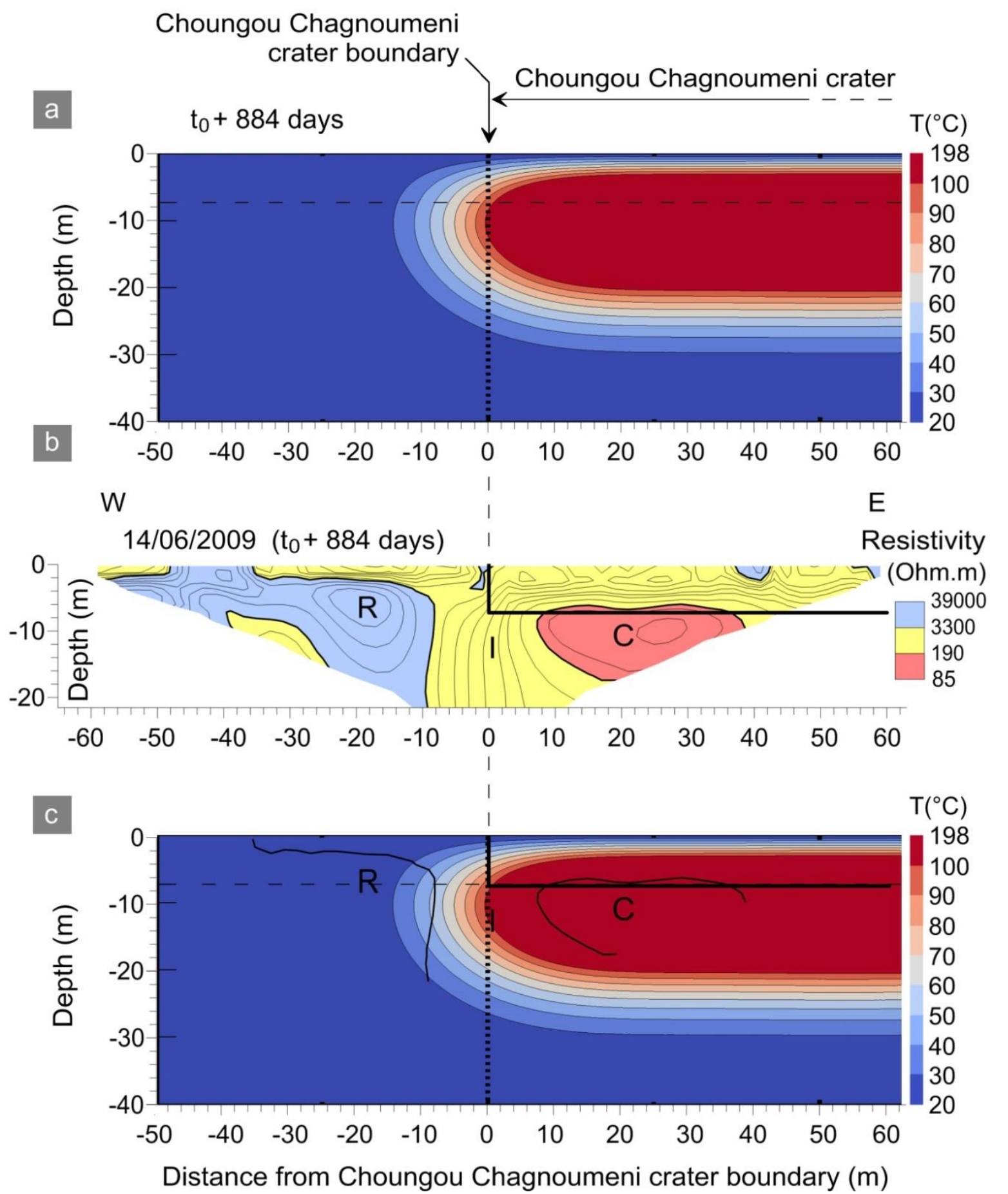

Figure 8: (a) 2D results obtained with the numerical modeling for the temperature of the lava flow cooling inside the Choungou Chagnoumeni crater at $t_{0}+884$ days; (b) Electrical resistivity tomography (ERT) profile showing the three ranges of resistivity values identified through the probability plot technique; (c) Superimposition of the results obtained with the numerical modeling with the two boundaries subdividing the three ranges of resistivity values. "R", "I" and "C" stand for Resistant, Intermediate and Conductive body, respectively. Note that " $\mathrm{C}$ " seems to be limited to $30 \mathrm{~m}$ in width, only due to the lateral limit in the ERT data acquisition. 
Therefore, we have to explain the good correlation between the highest temperature area (>100-200 $\left.{ }^{\circ} \mathrm{C}\right)$ and the most conductive body (85-190 Ohm.m).

With experimental petrology, measurements of electrical conductivity versus temperature are usually performed for high temperature $\left(>1000^{\circ} \mathrm{C}\right)$, close to liquidus conditions, in order to study the impact of partial crystallization on electrical conductivity (Scarlato et al., 2004: with basaltic rocks of Etna; Gaillard and Marziano, 2005: with samples of basaltic composition; Poe et al., 2008: with phonotephrite of Mt. Vesuvius). In both cases, the increase of temperature is always related with an increase of several orders of magnitude in conductivity.

The presence of water inside hydrous melts constitutes also another way to increase the conductivity, and the influence of water is more marked at low $\left(350-675^{\circ} \mathrm{C}\right)$ than high $(675$ $1325^{\circ} \mathrm{C}$ ) temperature (Pommier et al., 2008).

For temperature values closer from the temperature modeled for the Choungou Chagnoumeni lava flow, 884 days from the eruptive event (up to $198^{\circ} \mathrm{C}$ ), dry-silicate composition displays between 200 and $100^{\circ} \mathrm{C}$ a resistivity range from $10^{8}$ up to $10^{14} \mathrm{Ohm} . \mathrm{m}$ respectively (Pommier and Le-Trong, 2011). These values are very far away from the relatively low resistivity values measured in the field (85-190 Ohm.m). Therefore, the contribution of water to reduce the resistivity values needs to be taken into account.

For water saturated rocks, the resistivity values for dacitic and andesitic tuffs are between 30 and $428 \mathrm{Ohm} . \mathrm{m}$ with aqueous solution of $\mathrm{KCl}, 70 \mathrm{Ohm} . \mathrm{m}$ at $20^{\circ} \mathrm{C}$ (Llera et al., 1990). Although, in our case study, the rocks are never saturated, and the resistivity has to be higher, another parameter allows reducing the resistivity is the water temperature. Indeed, in the range of $10-200^{\circ} \mathrm{C}$, the resistivity decrease when temperature increase, and this decrease of resistivity reach two orders of magnitude between 10 and $200^{\circ} \mathrm{C}$ (Light, 1984; Light et al., 2005). The consideration of volcanic rock interconnected porosity in basalts (Al-Harthi, 1999; Sruoga et al., 2004), typical water conductivity and water content, and water temperature reaching up to $198^{\circ} \mathrm{C}$ allow to calculate with the literature cited above a range of resistivity in good accordance with our field data (between 85 and 190 Ohm.m). About the presence of water inside the Choungou Chagnoumeni crater, this latter can come from 1) mainly the raining events ( $\sim 6-10 \mathrm{~m} / \mathrm{yr}$ at the summit) and also 2$)$ from the preferential degassing way of the magma. This aspect has been already attested by the very high soil $\mathrm{CO}_{2}$ concentration associated with the profile crossing the Choungou Chagnoumeni crater (Fig. 3a). 
In conclusion, the slow cooling of the January $13^{\text {th }} 2007$ lava flow induce the presence of a residual heat, migrating in time, which maintain relatively high temperature $\left(100-200^{\circ} \mathrm{C}\right)$ for rocks and fluids. This parameter have a first order impact on the resistivity values measured, inducing low resistivity values associated with hot rock and fluid areas.

\subsection{Inversion in the shallow lateral temperature gradient}

The second part of the discussion have been orientated on the surprising result shown in Figs. $6 \mathrm{~b}$ and $6 \mathrm{c}$, with the inversion in time of lateral gradient measured at $30 \mathrm{~cm}$ depth. This inversion occurred between the second and the third monitoring period, so between $\mathrm{t}_{0}+650$ days and $t_{0}+885$ days.

This inversion is not in accordance with the temperature modeled with Rheolef, and can be explained only considering a convective heat transfer superimposed on the conductive heat transfer.

In order to validate the notion of convection and of heat moving faster than conductive phenomenon (thanks to mass transfer), we also analyzed, for each of the eleven heat temperature sensors, the average temperature variation per day. The basis of the reflection is the following. Considering that all the temperature sensors are located precisely at the same depth and covered by the same volcanic products, all the sensors will be influenced in the same way by all kind of external parameters (e.g. diurnal variation, raining events, or wind). The sensors affected by higher amplitude variations per day would be influenced by internal parameter with a relatively quick spatial displacement and with an origin located below the sensors. Only a lateral variation of permeability associated with preferential hydrothermal fluid flow could explain higher amplitude temperature variation (energy exchange) per day. In order to visualize such possible phenomenon, one average value was calculated for each sensor, during each one of the four periods of monitoring (Fig. 9). The results show clearly for the two first monitoring periods (red and green in Fig. 9) that the higher variations in the temperature per day are located toward the middle of the crater (sensors 5 up to 11), whereas for the two following periods of monitoring (blue and magenta in Fig. 9) the crater boundary of the Choungou Chagnoumeni crater (sensor 1) became the area of higher energetic exchange per day, for which a higher permeability have to be considered close to the crater boundary. 

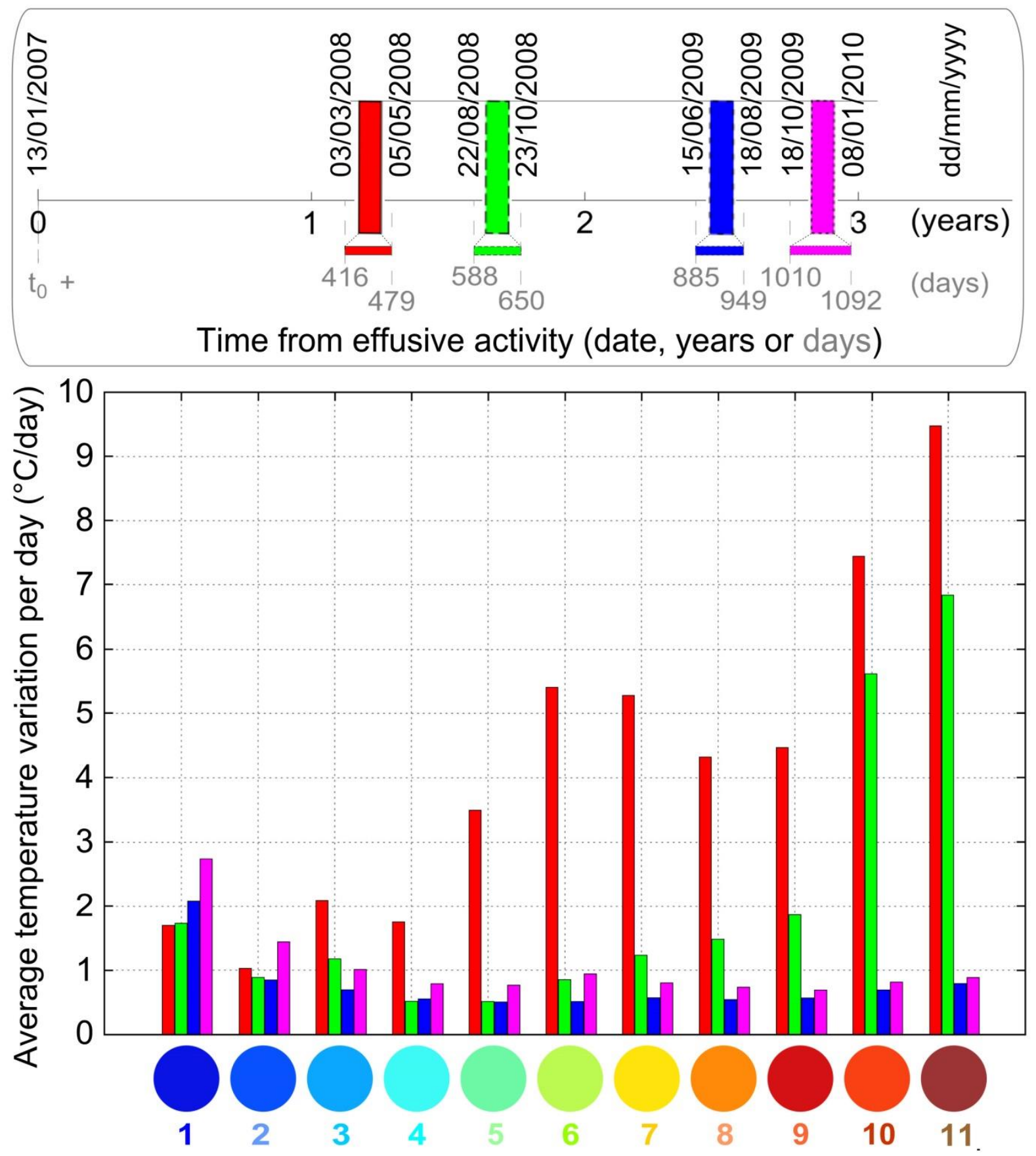

Distance from the Choungou Chagnoumeni crater boundary $(\mathrm{m})$

Figure 9: Average temperature variation per day, for each one of the eleven temperature sensors, and for each one of the four monitoring periods. 
This interpretation of change in lateral permeability along the structural boundary of Choungou Chagnoumeni crater can be closely associated with the decrease in $\mathrm{CO}_{2}$ concentration along a distance of $8 \mathrm{~m}$ from both part of the crater boundary. Such a local decrease of $\mathrm{CO}_{2}$ can be also explained with an increase of permeability, allowing to the air a preferential way to enter inside the hydrothermal system. Other examples of air circulation inside a crater have been studied in the literature (Antoine et al., 2009, 2017). Note that this hypothesis of higher air content along the crater boundary is also supported by the narrow vertical resistant anomaly up to $3 \mathrm{~m}$ depth located exactly on the crater rim.

The lateral lithological and permeability transition bordering the crater rim have not been integrated into the model and can explain some spatial discrepancy between our field data and the model.

The concept of structural boundary (such as crater or caldera boundaries) dragging preferentially hydrothermal fluids toward the surface have been described by different authors coupling geo-electricity, temperature and diffuse degassing (Finizola et al., 2002, 2003, 2006, 2009 ; Revil et al., 2004, 2008, 2011; Barde-Cabusson et al., 2008; Carapezza et al., 2009; Bennati et al., 2011; Peltier et al., 2012).

The originality in this study have been to pointed out, at shallow depth $(30 \mathrm{~cm})$, the transition between an initial heat regime, mainly governed by the location of the heat source and a second heat regime, where permeability of structural boundaries begin to play a major role for the shallow heat transfer.

In our study, this transition occurred at $30 \mathrm{~cm}$ depth, approximately 2 years after the effusive event, but it is interesting to note that, at depth, the influence of the heat source will remain for a longer time, as shown for instance in the first order information of the ERT profile, performed at the beginning of the third monitoring period $\left(\mathrm{t}_{0}+884\right.$ days $)$.

The inversion in time in the shallow lateral temperature gradient, (1) from a period dominated by the importance of the heat source in the convective heat transfer to (2) a period dominated by the importance of a structural boundary of higher permeability has been schematize in Fig. 10.

The coupling of the ERT, temperature monitoring and temperature modeling techniques allow us to better understand the spatio-temporal evolution related to lava flow cooling. 
Time from effusive activity (years or days)
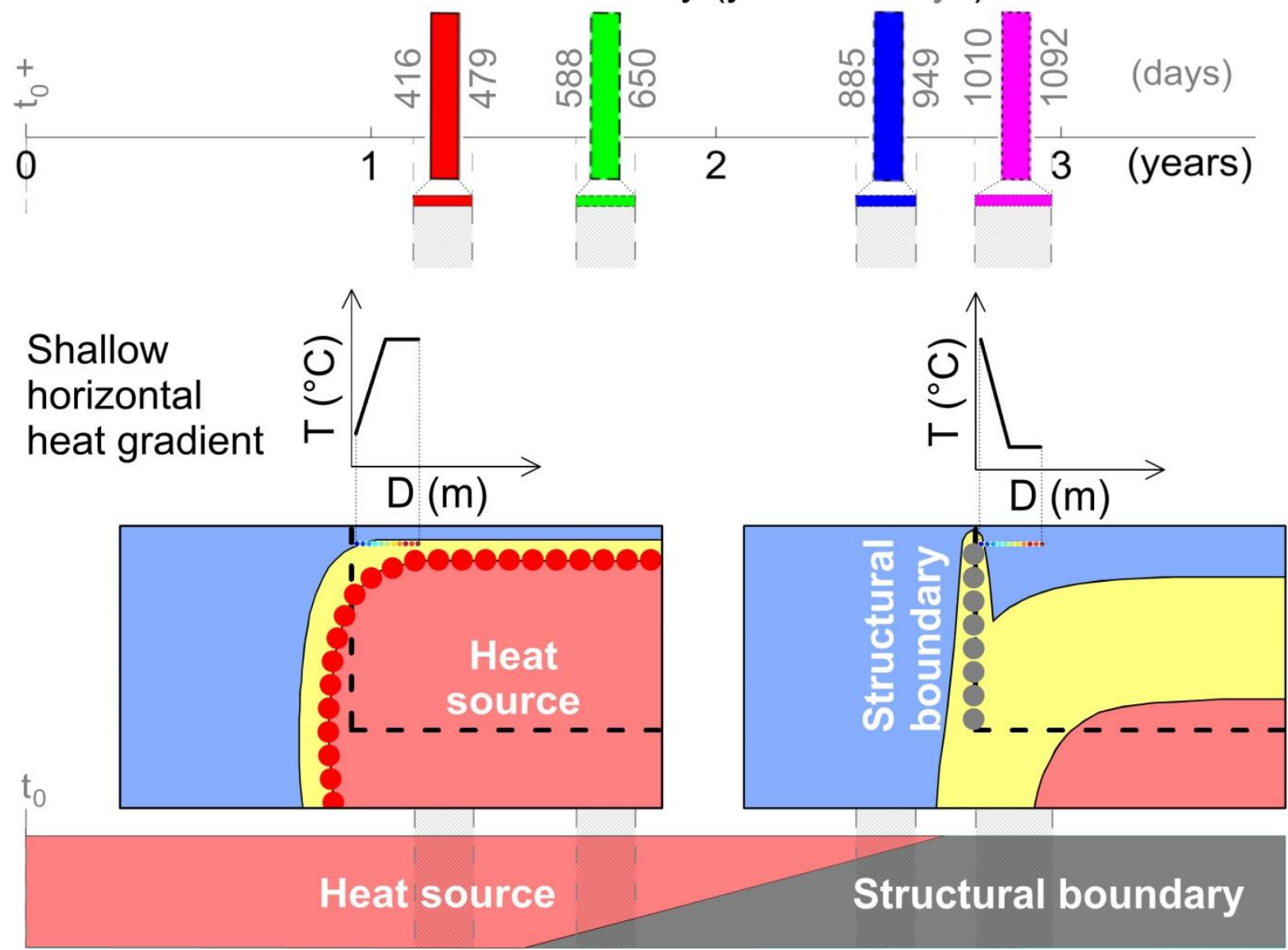

Figure 10: Conceptual model with time evolution of the main parameter impacting the heat transfer at $30 \mathrm{~cm}$ depth on a crater boundary refilled by a lava flow. 


\section{Conclusion}

The unusual simplicity in the cylindrical geometry of the lava flow which refilled in January $13^{\text {th }} 2007$ the Choungou Chagnoumeni crater in the summit part of Karthala volcano, allow a special study of spatio-temporal evolution of temperature and fluid flow through a new thermo-lithological boundary.

The multidisciplinary approach associating ERT measurements displayed, 884 days after this effusive event, the spatial convergence between the lowest resistivity measured and the hottest area modeled. According to the good correlation obtained in this work, it appears clearly that for hot temperature boundaries $\left(100-200^{\circ} \mathrm{C}\right)$, temperature constitutes the main parameter influencing resistivity data.

The lateral permeability transition related to the crater boundary was attested by the lower $\mathrm{CO}_{2}$ value associated with air contamination along the soil diffuse degassing profile. This survey also revealed the importance in structural boundaries, such as crater rims, in constituting preferential way for dragging convective mass and heat transfer, up to reverse in time the temperature gradient. This latter is influenced firstly by the hot lava, and after a period of cooling, structural boundary and the highest permeability area become the first parameter influencing the temperature gradient and fluctuation in time.

\section{Acknowledgements}

This work benefited from an important technical support of STRATAGEM974 geophysical company. We thank Mogne Ali Moussa from Volcanological Observatory of Karthala (OVK) to have changed two times the battery of the Campbell Scientific datalogger on the top of Karthala volcano. We are grateful to Marie Crovisier, Sophie Giannesini, Hamidou Nassour and François Sauvestre for their help in installing the Campbell Scientific datalogger and sensors in March 2008, and Aline Peltier, Fabrice Fontaine, Ludovic Leduc, and Loïc Jullien for their help in installing the ERT profile, $2 \mathrm{~m}$ spacing, crossing the Chagnoumeni crater, in June 2009. $\mathrm{CO}_{2}$ concentration measurements were performed thanks to the IR portable spectrometer built by Fabio Di Gangi (INGV-Palermo). The March 2008 field campaign and scientific monitoring equipment installed on the top of Karthala was funded by the PNUD (Programme des Nations Unies pour le Développement) program on Karthala volcano, and the June 2009 field campaign was funded by the Conseil Régional de La Réunion (“CORECOM” project FRROI : Fédération des Recherches Réunion, Océan Indien) through 
the University of La Réunion and Laboratoire GéoSciences Réunion-IPGP. NB was funded by the Agence National de la Recherche (ANR: http://www.agence-nationale-recherche.fr) through project ANR-LAVA (ANR Program: DS0902 2016; Project: ANR-16 CE39-0009, Link: www.agence-nationale-recherche.fr/?Project=ANR-16-CE39- 0009). This is ANRLAVA contribution no. $X$.

We specially thank Colonel Ismael Mogne Daho (COSEP) for providing military troops to bring our equipment for the two missions performed on the top of Karthala volcano, and Hamid Soulé, head of the Karthala Volcano Observatory for the logistical support. We are grateful to Nicolas Villeneuve for interesting discussions. We sincerely thank Diego Coppola and an anonymous reviewer for their time and constructive remarks which improved significantly the quality of the manuscript. This is IPGP contribution number XXXX.

\section{References}

Adrian B., Allan D. K., 2003. Heat transfer handbook. New Jersey.

Al-Harthi A. A., Al-Amri R. M., ShehataW. M., 1999. The porosity and engineering properties of vesicular basalt in Saudi Arabia. Engineering Geology, 54(3-4), 313-320.

Antoine R., Baratoux D., Rabinowicz M., Fontaine F., Bachèlery P., Staudacher T., Saracco G., Finizola A., 2009. Thermal infrared image analysis of a quiescent cone on Piton de la Fournaise volcano: Evidence of convective air flow within an unconsolidated soil. J. Volcanol. Geotherm. Res., 183, 228244,https://doi.org/10.1016/j.jvolgeores.2008.12.003

Antoine R., Finizola A., Baratoux D., Rabinowicz M., Lopez T., Saracco G., Hermitte D., Delcher E., Fontaine F.R., Darrozes J., Gabalda G., Bachèlery P., Staudacher T. 2017. Electric Potential anomaly induced by humid air convection within Piton de La Fournaise volcano, La Réunion Island. Geothermics., 65, 81-98, doi: 10.1016/j.geothermics.2016.01.003Aubert M., 1999. Practical evaluation of steady heat discharge from dormant active volcanoes: case study of Vulcarolo fissure (Mount Etna, Italy). J. Volcanol. Geotherm. Res. 92:413-429.

Aubert M., Diliberto S., Finizola A., Chébli Y. 2008. Double origin of hydrothermal convective flux variations in the Fossa of Vulcano (Italy). Bull. Volcanol., 70, 743751, https://doi.org/10.1007/s00445-007-0165-y

Bachèlery P., Ben Ali D., Desgrolard F., Toutain J.P., Coudray J., Cheminée J.L., Delmond J.C., Klein J.L. 1995. L'éruption phréatique du volcan Karthala (Grande Comore) en 
Juillet 1991: première crise sismo-volcanique suivie depuis l'implantation d'un réseau de surveillance. Comptes Rendus Académie Sciences Paris, t 320, Issue 8, Série II a, 691-698.

Bachèlery P., Coudray J., 1993. Carte volcano-tectonique (1/50.000 $)$ de la Grande Comore et notice explicative, 1-39. Edited by the French Embassy in Moroni, Comores, and The University of La Réunion, St. Denis de La Réunion.

Bachèlery P., Hémond C., 2016. Geochemical and Petrological Aspects of Karthala Volcano. In: Bachelery P., Lénat JF., Di Muro A., Michon L. (eds) Active Volcanoes of the Southwest Indian Ocean. Active Volcanoes of the World. Springer, Berlin, Heidelberg, 367-384, https://doi.org /10.1007/978-3-642-31395-0_23

Bachèlery P., Morin J., Villeneuve N., Soulé H., Nassor H., Ali A.R., 2016. Structure and Eruptive History of Karthala Volcano. In: Bachelery P., Lénat JF., Di Muro A., Michon L. (eds) Active Volcanoes of the Southwest Indian Ocean. Active Volcanoes of the World. Springer, Berlin, Heidelberg, 345-366, https://doi.org/10.1007/978-3-642-31395-0_22

Barde-Cabusson S., Finizola A., Revil A., Ricci T., Piscitelli S., Rizzo E., Angeletti B., Balasco M., Bennati L., Byrdina S., Carzaniga N., Crespy A., Di Gangi F., Morin J., Perrone A., Rossi M., Roulleau E., Suski B., Villeneuve N., 2009a. New geological insights and structural control on fluid circulation in La Fossa cone (Vulcano, Aeolian Islands, Italy). J. Volcanol. Geotherm. Res., 185, 231-245, https://doi.org/10.1016/j.jvolgeores.2009.06.002

Barde-Cabusson S., Levieux G., Lénat J.-F., Finizola A., Revil A., Chaput M., Dumont S., Duputel Z., Guy A., Mathieu L., Saumet S., Sorbadère F., Vieille M. 2009b. Transient self-potential anomalies associated with recent lava flows at Piton de la Fournaise volcano (Réunion Island, Indian Ocean). J. Volcanol. Geotherm. Res., 187, 158-166, https://doi.org/10.1016/j.jvolgeores.2009.09.003

Bennati L., Finizola A., Walker J., Lopez D., Higuiera-Diaz C., Schütze C., Barahona F., Cartagena R., Conde V., Funes R., Rios C. 2011. Fluid circulation in a complex volcano-tectonic setting, inferred from self-potential and soil $\mathrm{CO}_{2}$ flux surveys: the Santa María - Cerro Quemado - Zunil volcanoes and Xela caldera (northwestern Guatemala). J. Volcanol. Geotherm. Res., 199, 216-229, https://doi.org/10.1016/j.jvolgeores.2010.11.008 
Bernabeu N., Saramito P., Smutek C., 2016. Modeling lava flow advance using a shallowdepth approximation for three-dimensional cooling of viscoplastic flows. Geological Society, London, Special Publications, 426(1), 409-423.

Brouwers M., 1973. Anjouan : Inventaire des terres cultivables et de leurs aptitudes culturales. Rapport I, IRAT, 96pp.

Carapezza M. L., Ricci T., Ranaldi M., Tarchini L., 2009. Active degassing structures of Stromboli and variations in diffuse $\mathrm{CO} 2$ output related to the volcanic activity. J. Volcanol. Geotherm. Res., 182 (3-4), 231-245.

Chevrel M. O., Labroquère J., Harris A. J. L., Rowland, S. K., 2018. PyFLOWGO: An opensource platform for simulation of channelized lava thermo-rheologicalproperties. Comput. \& Geosci., 111, 167-180.

Chiodini G., Cioni R., Marini L., Panichi C, 1995. Origin of the fumarolic fluids of Vulcano Island, Italy and implications for volcanic surveillance. Bull Volcanol., 57(2), 99-110.

Chiodini G., .Cioni R., Guidi M., Raco B., Marini L., 1998. Soil $\mathrm{CO}_{2}$ flux measurements in volcanic and geothermal areas. Appl. Geochem., 13-5, 543-552, https://doi.org/10.1016/S0883-2927(97)00076-0

Chiodini G., Frondini F., Cardellini C., Granieri D., Marini L., Ventura G. 2001. CO$_{2}$ degassing and energy release at Solfatara volcano, Campi Flegrei, Italy. J. Volcanol. Geotherm. Res., Solid Earth, 106(B8), 16213-16221,

Coppola D., Laiolo M., Cigolini C., Delle Donne D. and Ripepe M., 2015a. Enhanced volcanic hot-spot detection using MODIS IR data: results from the MIROVA system. Geological Society, London, Special Publications, 426, 181205, https://doi.org/10.1144/SP426.5

Coppola D., Macedo O., Ramos D., Finizola A., Delle Donne D., Del Carpio J., White R., McCausland W., Centeno R., Rivera M., Apaza F., Ccallata B., Chilo W., Cigolini C., Laiolo M., Lazarte I., Machaca R., Masias P., Ortega M., Puma N., Taipe E., $2015 b$. Magma extrusion during the Ubinas 2013-2014 eruptive crisis based on satellite thermal imaging (MIROVA) and ground-based monitoring. J. Volcanol. Geotherm. Res., 302, 199-201, https://doi.org/10.1016/j.jvolgeores.2015.07.005

Coppola D., Piscopo D., Staudacher T., Cigolini C., 2009. Lava discharge rate and effusive pattern at Piton de la Fournaise from MODIS data. J. Volcanol. Geotherm. Res., 184: 1-2, 174-192, https://doi.org/10.1016/j.jvolgeores.2008.11.031 
Coppola D., Cigolini C., 2013. Thermal regimes and effusive trends at Nyamuragira volcano (DRC) from MODIS infrared data. Bull. Volcanol., 75: 744, https://doi.org/10.1007/s00445-013-0744-z

Danes Z. F., 1972. Dynamics of lava flows. J. Geophy. Res., 77(8), 1430.

Deroussi S., Diament M., Feret J. B., Nebut T., Staudacher T., 2009. Localization of cavities in a thick lava flow by microgravimetry. J. Volcanol. Geotherm. Res., 184(1-2), 193198.

Dragoni M., 1989. A dynamical model of lava flows cooling by radiation. B.

Volcanol., 51(2), 88-95.

Finizola A., Revil A., Rizzo E., Piscitelli S., T. Ricci, Morin J., Angeletti B., Mocochain L. Sortino F., 2006. Hydrogeological insights at Stromboli volcano (Italy) from geoelectrical, temperature, and $\mathrm{CO}_{2}$ soil degassing investigations. Geophys. Res. Lett., 33, L17304, https://doi.org/10.1029/2006GL026842

Finizola A., Sortino F., Lénat J-F., Aubert M., Ripepe M., Valenza M., 2003. The summit hydrothermal system of Stromboli: New insights from self-potential, temperature, $\mathrm{CO}_{2}$ and fumarolic fluids measurements, with structural and monitoring implications. Bull. Volcanol., 65, 486-504, https://doi.org/10.1007/s00445-003-0276-Z

Finizola A., Aubert M., Revil A., Schütze C., Sortino F., 2009. Importance of structural history in the summit area of Stromboli during the 2002-2003 eruptive crisis inferred from temperature, soil $\mathrm{CO}_{2}$, self-potential, and electrical resistivity tomography. J. Volcanol. Geotherm. Res., 183, 213-227. https://doi.org/10.1016/j.jvolgeores.2009.04.002

Finizola A., Sortino F., Lénat J-F., Valenza M., 2002. Fluid circulation at Stromboli volcano (Aeolian Islands, Italy) from self-potential and soil gas surveys. J. Volcanol. Geotherm. Res., 116: 1-2, 1-18

Frenken K., 2005. Irrigation in Africa in figures: AQUASTAT Survey, Frenken K. (Ed.). Vol. 29. Food \& Agriculture Org, 8pp. 
Friedel S., Byrdina S., Jacobs F., Zimmer M., 2004. Self-potential and ground temperature at Merapi volcano prior to its crisis in the rainy season of 2000-2001. J. Volcanol. Geotherm. Res., 134: 3, 149-168, https://doi.org/10.1016/j.jvolgeores.2004.01.006

Gaillard, F., Marziano, G. I., 2005. Electrical conductivity of magma in the course of crystallization controlled by their residual liquid composition. J. Geophys. Res. Solid Earth, 110(B6).Gaudin D., Finizola A., Delcher E., Beauducel F., Allemand P., Delacourt C., Brothelande E., Peltier A., Di Gangi, F. 2015. Influence of rainfalls on heat and steam fluxes of fumarolic zones: Six months records along the Ty fault (Soufrière of Guadeloupe, Lesser Antilles). J. Volcanol. Geotherm. Res., 203, 273285, https://doi.org/10.1016/j.jvolgeores.2015.06.015

Gaudin D., Ricci T., Finizola A., Delcher E., Alparone S., Barde-Cabusson S., Brothelande E., Di Gangi F., Gambino S., Inguaggiato S., Milluzzo V., Peltier A., Vita F. 2017. Heat flux-based strategies for the thermal monitoring of sub-fumarolic areas: examples from Vulcano and La Soufrière de Guadeloupe. J. Volcanol. Geotherm. Res., 343, 122-134, https://doi.org/10.1016/j.jvolgeores.2017.06.021

Goodman T. R. 1964. Application of integral methods to transient nonlinear heat transfer. In Advances in heat transfer, 1, 51-122.

Harris A. J. L., Rowland S. K., 2001. FLOWGO: a kinematic thermo-rheological model for lava flowing in a channel. Bull. Volcanol., 63(1), 20-44.

Harris A. J. L., S. Blake, D. A. Rothery, and N. F. Stevens (1997), A chronology of the 1991 to 1993 Mount Etna eruption using advanced very high resolution radiometer data: Implications for real-time thermal volcano monitoring, J. Geophys. Res., 102:(B4), 7985-8003, https://doi.org/10.1029/96JB03388

Harris A. J. L., Dehn J., Patrick M., Calvari S., Ripepe M., Lodato L., 2005. Lava effusion rates from hand-held thermal infrared imagery: an example from the June 2003 effusive activity at Stromboli. Bull. Volcanol., 68: 2, 107-117, https://doi.org/10.1007/s00445-005-0425-7

Harris A. J. L., Flynn L. P., Rothery D. A., Oppenheimer C., Sherman S. B., 1999. Mass flux measurements at active lava lakes: Implications for magma recycling. J. Geophys. Res., Solid Earth. 104: B4, 7117-7136, https://doi.org/10.1029/98JB02731 
Harris A. J. L., Flynn L. P., Matías O., Rose W. I., 2002. The thermal stealth flows of Santiaguito dome, Guatemala: Implications for the cooling and emplacement of dacitic block-lava flows. GSA Bulletin, 114: 5, 533-546, http://dx.doi.org/10.1130/00167606(2002)114<0533:TTSFOS>2.0.CO;2

Hedenquist J. W., Henley R. W., 1985. Hydrothermal eruptions in the Waiotapu geothermal system, New Zealand; their origin, associated breccias, and relation to precious metal mineralization. Economic geology, 80 (6), 1640-1668.

Hedenquist J. W., Lowenstern J. B., 1994. The role of magmas in the formation of hydrothermal ore deposits. Nature, 370 (6490), 519.

Head J. W., Wilson L., 1986. Volcanic processes and landforms on Venus: Theory, predictions, and observations. J. Geophy. Res.: Sol. Ea., 91(B9), 9407-9446.

Huber C., Bachmann O., Manga M., 2009. Homogenization processes in silicic magma chambers by stirring and mushification (latent heat buffering). Earth Planet. Sc. Lett., 283(1-4), 38-47.

Keszthelyi L., 1995. A preliminary thermal budget for lava tubes on the Earth and planets. J. Geophy. Res.: Sol. Ea., 100(B10), 20411-20420.

Keszthelyi L., Harris A. J. L., Dehn J., 2003. Observations of the effect of wind on the cooling of active lava flows. Geophy. Res. Lett., 30(19).

Keszthelyi L., Denlinger R., 1996. The initial cooling of pahoehoe flow lobes. Bull. Volcanol., 58(1), 5-18.

Krafft M., 1982. L'éruption volcanique du Karthala : Avril1977 (Grande Comore, océan Indien). Comptes Rendus Acad. Sci. Paris, 294, 753-758

Laiolo M., Coppola D., Barahona F., Benítez J. E., Cigolini C., Escobar D., Funes R., Gutierrez E., Henriquez B., Hernandez A., Montalvo F., Olmos R., Ripepe M., Finizola A., 2017. Evidences of volcanic unrest on high-temperature fumaroles by satellite thermal monitoring: the case of Santa Ana volcano, El Salvador. J. Volcanol. Geotherm. Res., 340, 170-179, https://doi.org/10.1016/j.jvolgeores.2017.04.013 
Lénat J.-F., Robineau B., Durand S., Bachèlery P., 1998. A self-potential survey of the summit zone of Karthala volcano (Grande Comore). Comptes Rendus Acad. Sci. Paris, Earth Planet. Sci., 327, 781-788.

Light T. S., 1984. Temperature dependence and measurement of resistivity of pure water. Analyt. Chem., 56(7), 1138-1142.

Light T. S., Licht S., Bevilacqua A. C., Morash K. R., 2005. The fundamental conductivity and resistivity of water. Electrochemical and Solid-State Letters, 8(1), E16-E19.

Llera F. J., Sato M., Nakatsuka K., Yokoyama H., 1990. Temperature dependence of the electrical resistivity of water-saturated rocks. Geophysics, 55(5), 576-585.

Loke, M. H., Barker, R. D., Rapid least-squares inversion of apparent resistivity pseudosections by a quasi-Newton method 1. Geophy. prospec., 1996, 44(1), 131-152

Michon L., 2016. The volcanism of the Comores archipelago integrated at a regional scale. In: Bachelery P., Lénat JF., Di Muro A., Michon L. (eds) Active Volcanoes of the Southwest Indian Ocean. Active Volcanoes of the World. Springer, Berlin, Heidelberg, 233-244, https://doi.org/10.1007/978-3-642-31395-0_21

Mirhani N., 2014. Dynamiques d'évolution des géosystèmes en milieu tropical humide insulaire : Approche par les bassins versants d'Anjouan aux Comores. Géographie. Université d'Angers; Université de Toliara. Français. PhD tesis. 256pp.

Morin J, Bachèlery P, Soulé H, Nassor H (2016) Volcanic and crisis management on Grande Comore island. In:Bachèlery P, Lénat J-F, Di Muro A, Michon L (eds) Active Volcanoes of the Southwest Indian Ocean: Piton de la Fournaise and Karthala. Active volcanoes of the World. Springer, Berlin (Chapter 25).

Neri A., 1998. A local heat transfer analysis of lava cooling in the atmosphere: application to thermal diffusion-dominated lava flows. J. Volcanol. Geoth. Res., 81(3-4), 215-243.

Ozisik M. N., 1993. Heat conduction. John Wiley \& Sons.

Peck D. L., Hamilton M. S., Shaw H. R., 1977. Numerical analysis of lava lake cooling models; Part II, Application to Alae lava lake, Hawaii. Am. J. Sci., 277(4), 415-437.

Peltier A., Finizola A., Douillet G., Brothelande E., Garaebiti E., 2012. Structure of an active volcano associated with a resurgent block inferred from thermal mapping: the Yasur-Yenkahe volcanic complex (Vanuatu). J. Volcanol. Geotherm. Res. 243-244, 59-68, https://doi.org/10.1016/j.jvolgeores.2012.06.022 
Poe B. T., Romano C., Varchi V., Misiti V., \& Scarlato P., 2008. Electrical conductivity of a phonotephrite from Mt. Vesuvius: The importance of chemical composition on the electrical conductivity of silicate melts. Chem. Geol., 256(3-4), 193-202.

Pommier A., Le-Trong E., 2011. "SIGMELTS”: A web portal for electrical conductivity calculations in geosciences. Computers \& Geosciences, 37(9), 1450-1459.

Pommier A., Gaillard F., Pichavant M., Scaillet B., 2008. Laboratory measurements of electrical conductivities of hydrous and dry Mount Vesuvius melts under pressure. Journal of Geophysical Research: Solid Earth, 113(B5).

Pucci S., Civico R., Villani F., Ricci T., Delcher E., Finizola A., De Martini P. M., Pantosti D., Sapia V., Barde-Cabusson S., Brothelande E., Gusset R., Mezon C., Orefice S., Peltier A., Poret M., Torres L., Suski B., 2016. Deep Electrical Resistivity Tomography along the tectonically active Middle Aterno Valley (2009 L'Aquila earthquake area, Central Italy). Geophys. J. Int., 207, 967-982, https://doi.org/ 10.1093/gji/ggw308

Revil A., Finizola A., Piscitelli S., Rizzo E., Ricci T., Crespy A., Angeletti B., Balasco M., Barde Cabusson S., Bennati L., A. Bolève., Byrdina S., Carzaniga N., Di Gangi F., Morin J., Perrone A., Rossi M., Roulleau E., Suski B., 2008. Inner structure of La Fossa di Vulcano (Vulcano Island, southern Tyrrhenian Sea, Italy) revealed by high resolution electric resistivity tomography coupled with self-potential, temperature, and $\mathrm{CO}_{2}$ diffuse degassing measurements. J. Geophys. Res., 113, B07207, https://doi.org/10.1029/2007JB005394

Revil A., Finizola A., Ricci T., Delcher E., Peltier A., Barde-Cabusson S., Avard G., Bailly T., Bennati L., Byrdina S., Colonge J., Di Gangi F., Douillet G., Lupi M., Letort J., and Tsang Hin Sun E., 2011. Hydrogeology of Stromboli volcano, Aeolian Islands (Italy) from the interpretation of resistivity tomograms, self-potential, soil temperature, and soil $\mathrm{CO}_{2}$ concentration measurements. Geophys. J. Int., 186, 1078-1094, https://doi.org/10.1111/j.1365-246X.2011.05112.x

Revil A., Finizola A., Sortino F., Ripepe M., 2004. Geophysical investigations at Stromboli volcano, Italy. Implications for ground water flow and paroxysmal activity. Geophys. J. Int., 157, 426-440, https://doi.org/10.1111/j.1365-246X.2004.02181.x

Revil A., Qi Y., Ghorbani A., Coperey A., Soueid Ahmed A., Finizola A., Ricci T., Induced polarization of volcanic rocks. Imaging clay cap properties in geothermal fields. Submitted to Geoph. J. Int. 
Ricci T., Finizola A., Barde-Cabusson S., Delcher E., Alparone S., Gambino S.. Miluzzo V., 2015. Hydrothermal fluid flow disruptions evidenced by subsurface changes in heat transfer modality: the La Fossa cone of Vulcano (Italy) case study. Geology. 43: 11, 959-962, http://dx.doi.org/10.1130/G37015.1

Savin C., Grasso J.R., Bachèlery P., 2005. Seismic signature of a phreatic explosion: hydrofracturing damage at Karthala volcano, Grande Comore Island, Indian Ocean. Bull. Volcanol., 67, 717-731, https://doi.org/10.1007/s00445-005-0411-0

Scarlato P., Poe B., Freda C., Gaeta M., 2004. HP-HT measurements of electrical conductivity in basaltic rocks fromMt. Etna (Sicily, Italy). J. Geophys. Res. 109, B02210.

Shaw H. R., Hamilton M. S., Peck D. L., 1977. Numerical analysis of lava lake cooling models; Part I, Description of the method. Am. J. Sci., 277(4), 384-414.

Sinclair, A. J., 1974. Selection of threshold values in geochemical data using probability graphs, J. Geochem. Explor., 3(2), 129-149.

Sruoga P., Rubinstein N., Hinterwimmer G., 2004. Porosity and permeability in volcanic rocks: a case study on the Serie Tobífera, South Patagonia, Argentina. . J. Volcanol. Geotherm. Res.,132(1), 31-43.

Strong D. F., Jacquot C., 1970. The Karthala Caldera, Grande Comore. Bull. Volcanol., 34: 3, 663-680, https://doi.org/10.1007/BF02596697

Wright R., Blake S., Harris A. J. L., Rothery D. A., 2001. A simple explanation for the spacebased calculation of lava eruption rates. Earth Planet. Sci. Lett., 192: 2, 223-233, https://doi.org/10.1016/S0012-821X(01)00443-5

Wright R., Flynn L. P., Garbeil H., Harris A. J. L., Pilger E., 2004. MODVOLC: near-realtime thermal monitoring of global volcanism. J. Volcanol. Geotherm. Res., 135: 1-2, 29-49, https://doi.org/10.1016/j.jvolgeores.2003.12.008 